\title{
Not Only Hydrogen Bonds: Other Noncovalent Interactions
}

\author{
Ibon Alkorta ${ }^{1, *(\mathbb{D})}$, José Elguero ${ }^{1, *}$ and Antonio Frontera $2, * \mathbb{D}$ \\ 1 Instituto de Química Médica, CSIC, Juan de la Cierva, 3, E-28006 Madrid, Spain \\ 2 Departament de Química, Universitat de les Illes Balears, Crta. de Valldemossa km 7.5, 07122 Palma de \\ Mallorca, Spain \\ * Correspondence: ibon@iqm.csic.es (I.A.); iqmbe17@iqm.csic.es (J.E.); toni.frontera@uib.es (A.F.)
}

Received: 11 February 2020; Accepted: 3 March 2020; Published: 6 March 2020

Abstract: In this review, we provide a consistent description of noncovalent interactions, covering most groups of the Periodic Table. Different types of bonds are discussed using their trivial names. Moreover, the new name "Spodium bonds" is proposed for group 12 since noncovalent interactions involving this group of elements as electron acceptors have not yet been named. Excluding hydrogen bonds, the following noncovalent interactions will be discussed: alkali, alkaline earth, regium, spodium, triel, tetrel, pnictogen, chalcogen, halogen, and aerogen, which almost covers the Periodic Table entirely. Other interactions, such as orthogonal interactions and $\pi-\pi$ stacking, will also be considered. Research and applications of $\sigma$-hole and $\pi$-hole interactions involving the p-block element is growing exponentially. The important applications include supramolecular chemistry, crystal engineering, catalysis, enzymatic chemistry molecular machines, membrane ion transport, etc. Despite the fact that this review is not intended to be comprehensive, a number of representative works for each type of interaction is provided. The possibility of modeling the dissociation energies of the complexes using different models (HSAB, ECW, Alkorta-Legon) was analyzed. Finally, the extension of Cahn-Ingold-Prelog priority rules to noncovalent is proposed.

Keywords: noncovalent interactions; Lewis acids; Lewis bases; spodium bonds; $\sigma / \pi$-hole interactions

\section{Introduction}

The aim of this review is to present an original, systematic and prospective view of all noncovalent interactions (NCI). There are several books treating different aspects of NCIs [1-4] but none offers a unified view of the subject, for instance the term Lewis acid/Lewis base does only appear in the most recent one [3]. See on this topic a recent conference paper entitled "Some interesting features of the rich chemistry around electron-deficient systems" [5].

We excluded hydrogen bonds from this survey on NCIs because they are well known and because the bibliography covering HBs is more extensive than the sum of the references on the other NCIs [6-11]. We also excluded anions and cations limiting this review to neutral molecules.

In the modified IUPAC periodic table of the elements reported in Figure 1, we noted in black all the NCIs reported up to now and in blue these not yet discussed. A similar representation was used by Caminati et al. for the front page of their publication [12]. They called the bonds of the groups MB (2), IB (13), TB (14), NB (15), CB (16), and XB (17) following previous authors. 


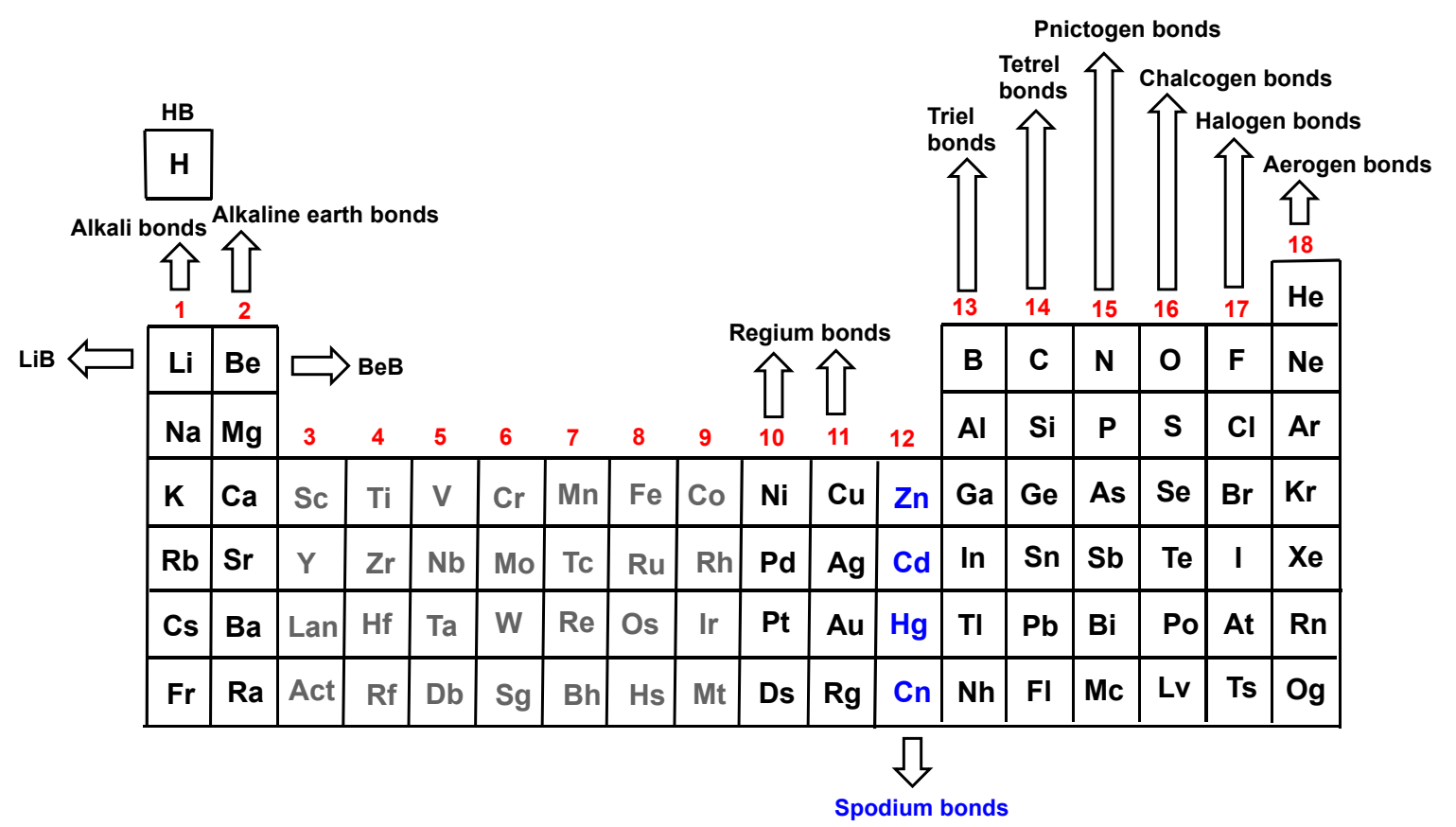

Figure 1. The different noncovalent bonds formed by elements of the Periodic Table. In black are accepted names, and in blue are the proposed new names. Groups 3 to 9 (in grey) are not included in this review.

Usually, the bond is associated with the Lewis acidity of a group, this is the case with groups 11, $13,14,15,16,17$, and 18. For groups 1 and 2, besides HBs, the bond is associated to an element, lithium, sodium and beryllium. We propose to call these bonds Alkali Bonds and Alkaline Earth Bonds (we used this name very recently) [13]. Although Regium Bonds were used for group 11, we propose to use it for both 10 and 11 groups. In grey are the atoms corresponding to groups 3 to 9 that we will not discuss, not that they were unable to form NCIs, but in order not to stretch too much this mini review.

Concerning the rows, we should indicate that $\mathrm{Li}, \mathrm{Be}, \mathrm{B}$, and $\mathrm{C}$ derivatives as Lewis acids have been more studied than $\mathrm{Na}, \mathrm{Mg}, \mathrm{Al}$, and $\mathrm{Si}$. On the other hand, $\mathrm{P}, \mathrm{S}$, and $\mathrm{Cl}$ are better representatives of their kind of NCIs than N, O, and F. This observation is related to size and to the softness of the Lewis acid atom that interacts with the Lewis base [14]

Gilbert N. Lewis published his interpretation of acid/base behavior in 1923 [15]; according to him any species with a reactive vacant orbital or available lowest unoccupied molecular orbital is classified as a "Lewis acid" [14,16].

A Lewis base (LB) is associated with a region of the space where there is an excess of negative charge (electron density) in the proximity of an atom or several atoms of a molecule. This happens in anions and in some neutral molecules, such as lone pairs (LP: carbenes, amines, phosphines, $N$-oxides, ... ), multiple bonds (olefins, acetylenes, benzenes, and other aromatic molecules, ... ), single bonds (alkanes, dihydrogen, ... ), radicals, metals (rare), ...

A Lewis acid (LA) is associated with a region of the space where there is an excess of positive charge (a deficit of negative charge, electron deficiency) in the proximity of an atom or several atoms of a molecule. This happens in cations, $\sigma$ - and $\pi$-holes, metals (frequent), $\ldots$ The concepts of $\sigma$-hole and $\pi$-hole were introduced by Politzer et al. [17-19] to describe regions of positive potential along the vector of a covalent bond ( $\sigma$-hole) or perpendicular to an atom of molecular framework ( $\pi$-hole).

Some atoms have simultaneously (but in different parts of the space) LB and LA zones due to their anisotropic distribution of electron density. The same happens for molecules, but in this case, they correspond to different parts of the molecule. Note that some Lewis acids when interacting with stronger Lewis acids can behave as Lewis bases [20]. 
When an LB and an LA containing atoms or molecules are free to interact (i.e., non restrained by some geometrical hindrance), they form complexes being their minima or transition states of different order.

The information on NCIs is mostly based on from crystal structures, microwave (MW) spectroscopy and theoretical calculations; consequently, they are related to gas-phase and solid state. Since chemistry is mainly done in solution there is a consistency problem.

Another aspect that is common to all NCIs is cooperativity. The natural evolution of theoretical studies has been moving from dimer complexes to trimers and longer complexes in search of cooperativity, both augmentative and diminutive, present in crystal structures.

Definition: Noncovalent interactions are complexes formed by two or several LBs and LAs. It is the LA that gives the name to the interaction. Dative bonds are included in this definition.

Why were the complexes not named according to the LB? Historically, because all NCI derive from HBs, i.e., where the H-bond donor is the Lewis acid. More fundamentally, it is because it is not possible to define families of NCIs based on LB. For instance, all anions are LBs, and anions can be found all over the Periodic Table. A classification of LBs is given in Figure 2.

\begin{tabular}{|l|l|l|l|l|}
\hline Anions & \multicolumn{3}{|c|}{ Neutral molecules } \\
\hline & Atoms & Bonds & Rings & Groups \\
\hline $\mathrm{H}^{-}$ & $\mathrm{He}$ & $\mathrm{H}-\mathrm{H}$ & \\
\hline $\mathrm{CN}^{-}$ & & $\mathrm{H}-\mathrm{H}$ & $\mathrm{BrCH}_{3}$ \\
\hline
\end{tabular}

Figure 2. Lewis bases involved in noncovalent interactions.

The proposed definition allows naming immediately the famous $\mathrm{H}_{3} \mathrm{~N}: \mathrm{BH}_{3}$ complex [21]; since $\mathrm{BH}_{3}$ is the LA, this is an example of triel bond. The recent controversy Zhou-Frenking/Landis-Weinhold on the $\mathrm{Ca}(\mathrm{CO})_{8}$ complex [22-24] leads us to propose the classify them as alkaline earth bonds, the $\mathrm{CO}$ being the Lewis bases.

In a recent paper, it is written: "It is well known that alkynes act as $\pi$-acids in the formation of complexes with metals" [25]. If this were correct, then the bond should be a tetrel one; on the other hand, if the alkyne was the base and the metal (in this case Au) the Lewis acid [14], the bond would be a regium bond.

This review does not try to discuss the nature of the bonds [26] we classified as NCIs. This is still a subject not settled [27]. For instance, Mo et al., using the block-localized wave function (BLW), analyzed the halogen bond [28], concluding that it is a charge transfer (CT) interaction, i.e., an intermolecular hyperconjugation consistent with Mulliken proposal [29]. The same authors used the BLW methodology to analyze hydrogen, halogen, chalcogen, and pnictogen bonds, stressing the magnitude of covalency, directionality, and $\sigma$-hole concept [30]. A review by Jin et al. [31] compared the $\sigma$-hole and $\pi$-hole bonds based on halogen bonds. Grabowski et al. [32] discussed halogen, chalcogen, pnictogen, and tetrel bonds as LA-LB complexes.

\section{Alkali Bonds}

The oldest of NCIs (not including HBs) are the Halogen Bonds that, although not named like this, were reported in 1948-1950 by Benasi, Hildebrand, and Mulliken [29,33]. Lithium Bonds were introduced by three great chemists: Kollman, Liebman, and Allen in 1970 [34]. We contributed with a 
paper [35] to this field, where we studied $\mathrm{F}-\mathrm{Li} \cdots \mathrm{N}, \mathrm{H}-\mathrm{Li} \cdots \mathrm{N}$ and $\mathrm{H}_{3} \mathrm{C}-\mathrm{Li} \cdots \mathrm{N}$ lithium bonds. The set of nitrogen Lewis bases consists of two that are sp hybridized $\left(\mathrm{N}_{2}\right.$ and $\left.\mathrm{HCN}\right)$; five $\mathrm{sp}^{2}$-hybridized bases, four of which are aromatic (1,3,5-triazine, 1,2,3-triazine, pyrazine, and pyridine), one nonaromatic $\left(\mathrm{HN}=\mathrm{CH}_{2}\right)$; and three $\mathrm{sp}^{3}$-hybridized bases $\left(\mathrm{NH}_{3}, \mathrm{NH}_{2} \mathrm{CH}_{3}\right.$, and aziridine).

There have been two theoretical papers reporting Sodium bonds [36,37] but, so far, none reporting Potassium bonds. For consistency reasons, we propose to call all of them Alkali bonds. The paper on sodium bonds reported cooperativity between halogen and sodium bonds in NCX $\cdots$ NCNa $\cdots \mathrm{NCY}$ complexes, where $\mathrm{Y}=\mathrm{F}, \mathrm{Cl}, \mathrm{Br}, \mathrm{I}$, and $\mathrm{Y}=\mathrm{H}, \mathrm{F}, \mathrm{OH} .{ }^{15} \mathrm{~N}$ chemical shifts were used to quantify the cooperativity [36].

Although we have excluded cations from this review, we would like to report our studies involving the lithium cation. One characterizing the $\mathrm{F}-\mathrm{Li}^{+}-\mathrm{F}$ lithium bonds [38]; a number of homo-dimer and hetero-dimer complexes were studied $\left(\mathrm{H}_{3} \mathrm{C}-\mathrm{F}-\mathrm{Li}^{+} \ldots \mathrm{F}_{2}, \mathrm{H}_{3} \mathrm{C}-\mathrm{F}-\mathrm{Li}^{+} \ldots \mathrm{F}-\mathrm{H}, \mathrm{Cl}-\mathrm{F} \cdots \mathrm{Li}^{+} \ldots \mathrm{F}-\mathrm{Cl}\right.$, $\left.\mathrm{F}_{2} \cdots \mathrm{Li}^{+} \ldots \mathrm{F}_{2}, \ldots\right)$ and the spin-spin coupling constants (SSCC) calculated. A different approach was used to study the 1:1 and 2:1 complexes between hydrogen peroxide and its methyl derivatives with lithium cation in order to find if a huge static homogeneous electric field perpendicular to the magnetic field of the NMR spectrometer is able to differentiate enantiomers [39].

\section{Alkaline Earth Bonds}

Initially, this topic started with Beryllium bonds [40,41] and further extended to magnesium and calcium bonds along Group 2. Kollman, Liebman, and Allen suggested, in 1970, studying $\mathrm{H}_{2} \mathrm{Be} \cdots \mathrm{OH}_{2}$, while they explained that $\mathrm{HBeF}$ is isoelectronic to $\mathrm{HCN}$ [34]. We contributed to this topic starting with a paper of 2009 entitled "Beryllium bonds, do they exist?" [42]. There, we noted that inorganic chemists have described $\mathrm{BeX}_{2} \mathrm{~L}_{2}$ compounds in which $\mathrm{X}=\mathrm{F}, \mathrm{Cl}, \mathrm{Br}$, and $\mathrm{L}=\mathrm{NH}_{3}$ and other Lewis bases (for more recent papers concerning these complexes, see [43,44], and note that they do not call them beryllium bonds).

Beryllium bonds can modulate the strength of HBs (cooperativity) [45], transform azoles into gas-phase superacids [46], create $\sigma$-holes in molecules that are devoid of them (like $\mathrm{CH}_{3} \mathrm{OF}$ ) [47], spontaneous production of radicals [48], beryllium based anion sponges [49], etc.

Magnesium bonds were explored later on. Thus, Q. Li et al. studied the $\mathrm{H}_{2} \mathrm{NLi} \cdots \mathrm{HMgX}$ complexes where $\mathrm{X}=\mathrm{H}, \mathrm{F} . \mathrm{Cl}, \mathrm{Br}, \mathrm{CH}_{3}, \mathrm{OH}$ and $\mathrm{NH}_{2}$ that are stabilized though a combination of magnesium and lithium bonds [50]. Scheiner et al. reported the effect of magnesium bonds on the competition between hydrogen and halogen bonds [51]. Montero-Campillo et al. discussed the synergy between tetrel bonds and alkaline earth bonds resulting in weak interactions getting strong [13]. Although $\mathrm{NCI}$ are generally studied in intermolecular complexes, there is a paper describing intramolecular magnesium bonds in malonaldehyde-like systems [52].

High-level calculations, using the complete basis set (CBS) extrapolation [CCSD(T)/CBS] of $\mathrm{B} \cdots \mathrm{BeR}_{2}$ and $\mathrm{B} \cdots \mathrm{MgR}_{2}$ complexes were carried out where $\mathrm{B}$ is a $\mathrm{LB}$ and $\mathrm{R}=\mathrm{F}, \mathrm{H}$ and $\mathrm{CH}_{3}$ [53]. The $\mathrm{Mg}$ series show smaller electrophilicities than the Be series.

Finally, calcium bonds were studied in comparison with beryllium and magnesium bonds at producing huge acidity enhancements [54].

Although some authors have started calling them alkaline earth bonds [13,54], its use has still not become the norm.

\section{Regium Bonds}

This name (they are also called Metal Coinage Bonds) [55-57] is usually given to Group 11; we propose to include also group $10(\mathrm{Ni}, \mathrm{Pd}, \mathrm{Pt}$ ). We cited $\mathrm{Pt}$ (group 10), Co, $\mathrm{Rh}$, and $\mathrm{Ir}$ (group 9) in a paper on regium bonds [55], but nobody reports these systems as NCIs.

It is necessary to clearly differentiate clusters (e.g., $\mathrm{Au}_{2}$ or $\mathrm{Ag}_{11}$ ) (Figure 3) [58] from molecules (e.g., $\mathrm{AuX}$ ) $[59,60]$. Brinck and Stenlid, based on their study of nanoclusters of $\mathrm{Cu}, \mathrm{Au}, \mathrm{Pd}, \mathrm{Pt}, \mathrm{Rh}, \ldots$ ), 
proposed a division of $\sigma$-holes, depending on the molecular electrostatic potential, into $\sigma_{s}, \sigma_{p}$, and $\sigma_{d}$-holes [61,62].
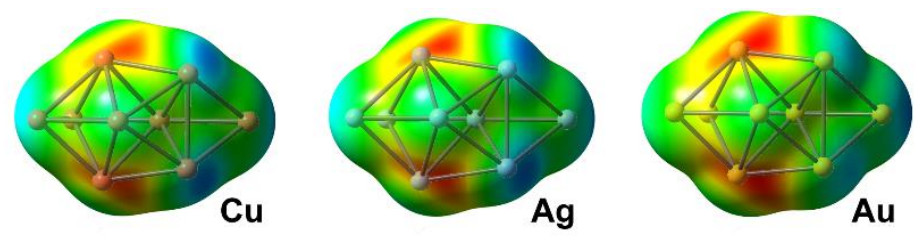

Figure 3. Coinage metal clusters [55].

The higher the oxidation degree (for instance, $\mathrm{Au}(\mathrm{III}) \mathrm{vs.} \mathrm{Au}(\mathrm{I})$ ) the more acidic the Lewis acid; see, for instance, the complex $\left(\mathrm{CF}_{3}\right)_{3} \mathrm{Au} \cdots$ pyridine [63]. We cited Legon in a 2014 paper [64] but did not define the $\mathrm{Cl}-\mathrm{Ag} \cdots \mathrm{C}_{2} \mathrm{H}_{2}$ complex as a regium bond (Figure 4):

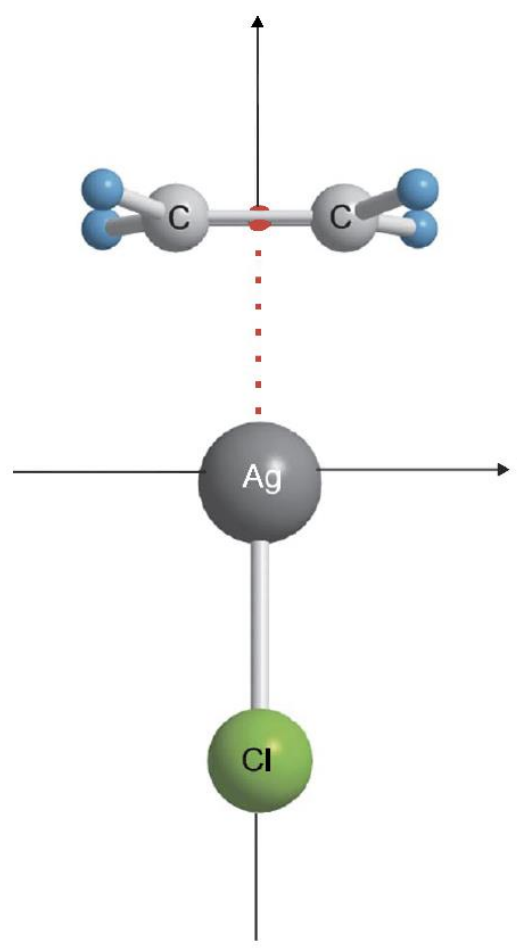

Figure 4. Experimental microwave (MW) structure of complex $\mathrm{C}_{2} \mathrm{H}_{4} \cdots \mathrm{Ag}-\mathrm{Cl}$.

In 2019, several papers were published on regium bonds, from which we have selected the following four Reference works [65-68].

A comparative study of the regium and hydrogen bonds in $\mathrm{Au}_{2}: \mathrm{HX}$ complexes was carried out at $\operatorname{CCSD}(\mathrm{T})$ level. In all cases, the regium bond complexes are more stable than HB ones. The binding energies for regium bonds complexes range between -24 and $-180 \mathrm{~kJ} \cdot \mathrm{mol}^{-1}$, whereas those of the HB complexes are between -6 and $-19 \mathrm{~kJ} \cdot \mathrm{mol}^{-1}$ [65]. Similarly, triel and regium bonds were compared, in particular they augmentative and diminutive interactions; the calculations were carried out at second order Møller-Plesset (MP2) perturbation theory [66]. For $\mathrm{Cu}, \mathrm{Ag}$, and $\mathrm{Au}$ atoms, the aug-cc-pVDZ-PP pseudopotential was used to account for relativistic effects.

A recent investigation described in detail the synthesis, $\mathrm{X}$-ray characterization, and regium bonding interactions in a trichlorido-(1-hexylcytosine)gold(III) complex [67]. Moreover, this study also included an interesting search in the CSD, revealing that this type of noncovalent interaction is recurrent in X-ray structures and has remained essentially unobserved because of the underestimated van der Waals radius value tabulated for gold. Figure 5 shows the self-assembled dimer that is formed 
in the solid state of trichlorido-(1-hexylcytosine)gold(III) where two symmetrically equivalent $\mathrm{Au} \cdots \mathrm{Cl}$ regium bonds are established.

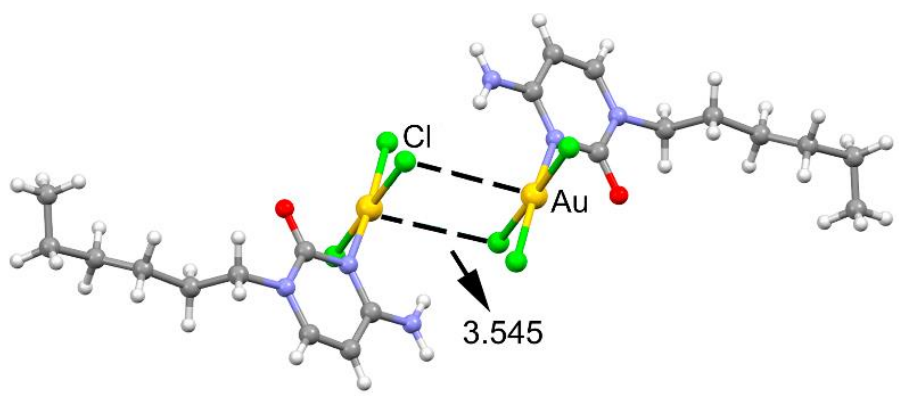

Figure 5. Self-assembled dimer of trichlorido-(1-hexylcytosine)gold(III) complex. Distance in $\AA$.

Finally, regium bonds formed by $\mathrm{MX}(\mathrm{M}=\mathrm{Cu}, \mathrm{Ag}, \mathrm{Au} ; \mathrm{X}=\mathrm{F}, \mathrm{Cl}, \mathrm{Br})$ with phosphine-oxide and phosphinous acid were studied comparing oxygen-shared and phosphine-shared complexes. These complexes were investigated by means of ab initio MP2/aug-cc-pVTZ method [68].

A comparative study of the Lewis acidities of gold(I) and gold (III), specifically ClAu and $\mathrm{Cl}_{3} \mathrm{Au}$, towards different ligands $(\mathrm{H}, \mathrm{C}, \mathrm{N}, \mathrm{O}, \mathrm{P}, \mathrm{S})$ was carried out at the CCSD(T)/CBS level (an example of $\mathrm{N}$ base is given in Figure 6) [69]. The dissociation energies of the complexes are consistent with Yamamoto model. This author, in three fundamental papers [70-72], signaled that $\mathrm{AuCl}_{3}$ behaves preferably as a $\sigma$-electrophilic Lewis acid with a $\eta^{1}$ hapticity typically towards heteroatom lone pairs, while $\mathrm{AuCl}$ behaves a $\pi$-electrophilic Lewis acid with a $\eta^{2}$ hapticity typically towards CC double and triple bonds. Amongst the unexpected findings is that both chlorides open the cyclopropane ring to afford a four-membered metallacycle and that the benzene complexes can show metallotropic shifts. Theoretical [73] and experimental [74] papers related to gold-arene structures have been published. Clearly, this field is one of higher growth in recent times.

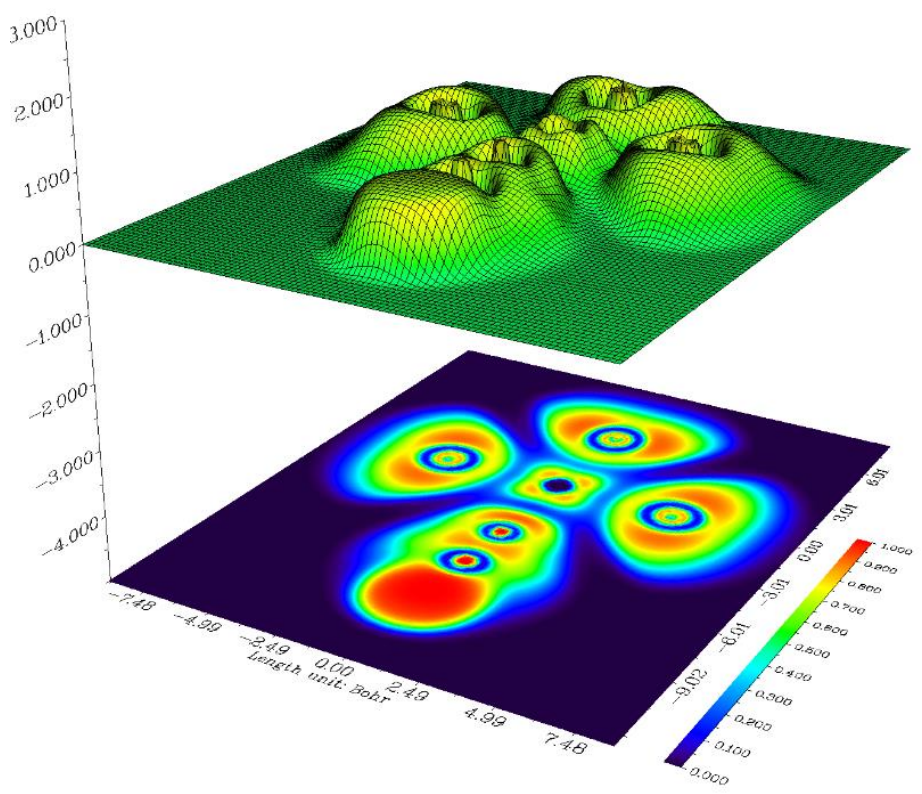

Figure 6. Electron localization function (ELF) analysis of the $\mathrm{Cl}_{3} \mathrm{Au} \cdots \mathrm{NCH}$ complex.

The nature of the $\mathrm{Au}-\mathrm{N}$ bond in $\mathrm{Au}(\mathrm{III})$ complexes with aromatic heterocycles led Radenkovic et al. to the conclusion that they have higher electrostatic than covalent character [75]. AIM analysis shows that the charge density of the $\mathrm{Au}-\mathrm{N}$ bond is depleted along the bond path. 


\section{Spodium Bonds}

As aforementioned, for elements of group 11 acting as electron acceptors, the name of regium bonds was proposed to define their interaction with Lewis bases. However, for the adjacent Group 12, the trivial name has not been yet defined. We propose herein to name these bonds "spodium bonds" because a derivative of the first element of the group $(\mathrm{ZnO})$ is called spodium in Latin. It is important to emphasize that the interesting and remarkable work of Joy and Jemmis [76] anticipated that metals of the twelfth group might also participate in noncovalent interactions as Lewis acids. Moreover, these authors also showed that for groups 3-10, this type of interaction (denoted generically as metal bonding) is very scarce. In fact, they searched the Cambridge Structural Database (CSD) [77] and could not find any standard 18-electron transition-metal complexes where the metal participates in a weak interaction of type $\mathrm{X}-\mathrm{M} \cdots: \mathrm{A}$ ( $\mathrm{A}=$ Lewis Base).

The lack of $\sigma$-hole bonding (or metal bonding) in groups 3-10 is due to the fact that the possible $\sigma$-hole on the metal center is screened by the core electrons and diminished charge polarization. This is explained by the minimal orbital coefficient on the LUMO in the R-M bond ( $\mathrm{M}$ belonging to groups 3-10). However, for metal complexes of elements of groups 11 and 12 (fully filled d orbitals), highly diffused valence $s$ and $\mathrm{p}$ orbitals can sustain the $\sigma$-hole and they are capable to form $\mathrm{M}$-bonds just like the main-group compounds. One of the first manuscripts describing spodium bonds was published by Chieh in 1977 [78]. It corresponds to a dichloro-bis(thiosemicarbazide)-mercury(II) complex that establishes highly directional spodium bonds. It can be clearly observed in Figure 7 that this compound forms in the solid state infinite 1D supramolecular chains where the electron donor (chlorido ligand) is located opposite to the polarized $\mathrm{Hg}-\mathrm{Cl}$ bond at a distance of $3.25 \AA$ that is slightly shorter than the sum of van der Waals radii (3.30 $\AA$ ) and significantly longer than the sum of covalent radii $(2.39 \AA)$, thus evidencing the noncovalent nature of the interaction.

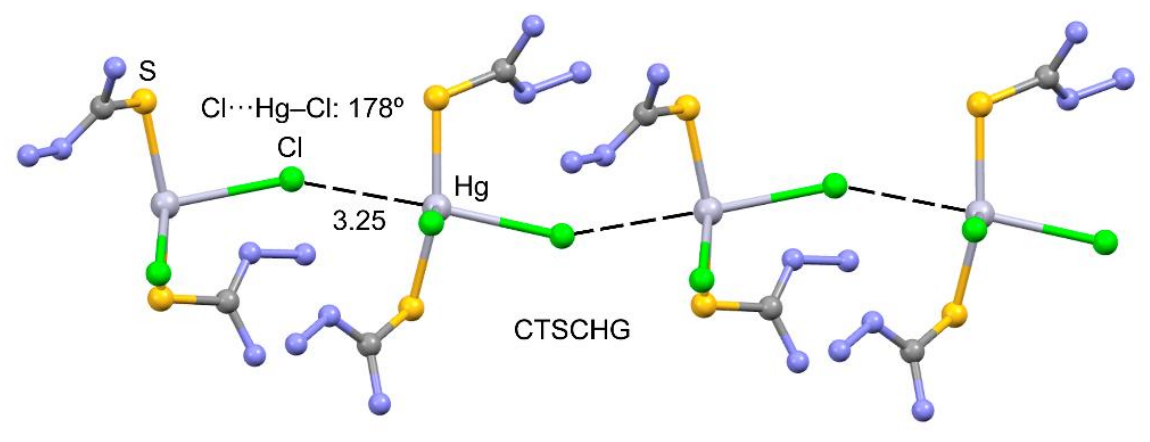

Figure 7. Spodium complexes of $\mathrm{ZnCl}_{2}$. Distances in $\AA$. The CSD reference code is indicated.

The nature of the metal $\cdots$ CO bonds in Group 12 metal carbonyl cations was analyzed by Frenking et al. [79] by studying the geometric and energetic features of their carbonyl complexes, which were also characterized using several computational tools like NBO and distribution of electron density. They showed that in Group 12 the $\mathrm{M}-\mathrm{CO}$ bond strength in $\left[\mathrm{M}(\mathrm{CO})_{n}\right]^{2+}$ complexes exhibits the trend $\mathrm{Zn}^{2+}>\mathrm{Hg}^{2+}>\mathrm{Cd}^{2+}$ and, interestingly, the bond energies are strong for $\mathrm{n}=1,2$, moderate for $\mathrm{n}=3,4$, and weak for $\mathrm{n}=5,6$. Moreover, they showed that Group 12 carbonyls $\left[\mathrm{M}(\mathrm{CO})_{n}\right]^{2+}$ exhibit mainly coulombic attraction with quite small covalent contributions apart from $[\mathrm{Hg}(\mathrm{CO})]^{2+}$ and $\left[\mathrm{Hg}(\mathrm{CO})_{2}\right]^{2+}$ complexes. In contrast, covalent contributions were shown to be significant in the metal carbonyls of Group 11.

It is worthy to highlight the investigation by Vargas et al. where the synthesis and X-ray characterization of unprecedented monomeric 16-electron $\pi$-diborene complexes of $\mathrm{Zn}$ (II) and Cd(II) are reported, which are good examples of noncovalent spodium bonds [80]. As a matter of fact, stable $\pi$-complexes of $\mathrm{d}^{10}$ transition metals like copper(I) and nickel( $(0)$ with olefins are known. However, such complexes involving $\mathrm{d}^{10} \mathrm{Zn}$ (II) are not known because the bond is too weak to generate isolable 
compounds. This fact was explained taking into consideration the limited capacity of elements of Group-12 for $\pi$-back-donation. Vargas et al. overcame this drawback by using neutral diborenes because this type of compounds exhibits a high-lying $\pi(\mathrm{B}=\mathrm{B}) \mathrm{HOMO}$ orbital. In fact, they were able to synthesize in good yields $\mathrm{M}(\mathrm{II})$-diborene $(\mathrm{M}=\mathrm{Zn}, \mathrm{Cd}) \pi$-complexes. In addition to their $X$-ray characterization in the solid state, they were also detected in solution by NMR and UV-visible absorption spectroscopy. The $\mathrm{M}(\mathrm{II})$ centers are located over the center of the $\mathrm{B}=\mathrm{B}$ bond and adopt a trigonal planar geometry almost equidistant to both boron atoms.

\section{Triel Bonds}

The name of triel bonding was proposed by Grabowski [81] in 2014 to describe the noncovalent interactions between elements of group 13 and electron rich atoms. However, the LA ability of triel atoms has been known for a long time [82-87]. In fact, trivalent triel compounds, such as trihydrides and trihalides, present a strong $\pi$-hole due to the empty $\mathrm{p}$ orbital, which is perpendicular to the plane of the molecule. This empty p-orbital determines the high directionality of the triel bonding. Since 2014, a number of experimental and theoretical studies have been published devoted to the study of the triel bond and its relation to reactivity [88-93]. As an example, in Figure 8, we show the X-ray structure of the hydrochloride of 4-pyridinylboronic acid, where the anion is located precisely over the B-atom in line with the location of the $\pi$-hole, as shown in the MEP surface (see Figure 8).
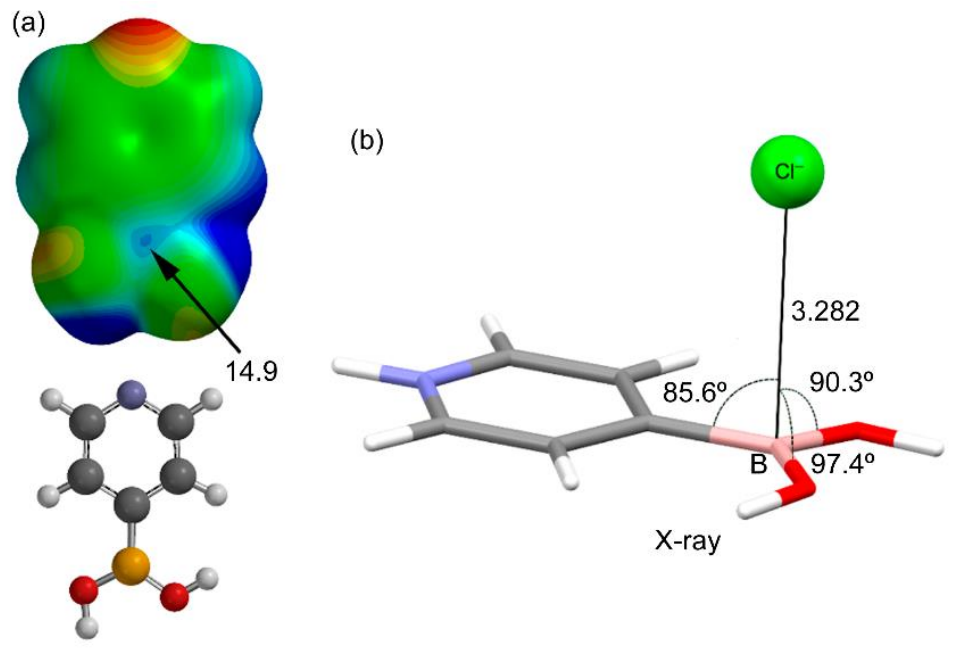

Figure 8. (a) Molecular electrostatic (MEP) surfaces of 4-pyridinylboronic acid with indication of the MEP value at the $\pi$-hole in $\mathrm{kcal} \cdot \mathrm{mol}^{-1}$. (b) X-ray structure of the hydrochloride of 4-pyridinylboronic acid. The anion is located over the $\pi$ hole at the boron atom. Distances in $\AA$.

Energetically, the triel bond is very strong and presents highly covalent character. Actually, Leopold et al. [94] have named these type of complexes as "partially bonded complexes" after performing a systematic investigation on the geometric features of triel bonding complexes. The equilibrium distances are intermediate between van der Waals contacts and covalent bonds. It is interesting to highlight the behavior of triel bonds depending on the state. For instance, the triel bonding complex between $\mathrm{F}_{3} \mathrm{~B}$ and acetonitrile exhibits a $\mathrm{B} \cdots \mathrm{N}$ distances that is $2.01 \AA$ in the gas phase and $1.63 \mathrm{~A}$ in the solid state due to cooperativity effects [95].

As a matter of fact, a significant attention has been paid to synergetic effects between triel bonds and a great deal of interactions, including hydrogen bonding [96], and other $\sigma$-hole based interactions in elements of group 17 [97], group 16 [98], group 15 [99], group 14 [100], and even regium bonding [66]. In these type of complexes, where two or more interactions coexist, the triel bond is usually the most favored one. Upon formation of the complex, the trivalent triel atom usually suffers a large deformation, changing its planar structure to a pseudo-tetrahedral one thus changing to an 


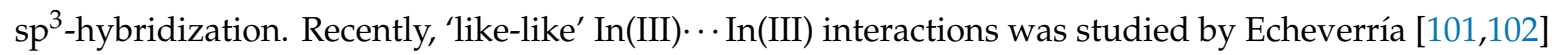
in the crystal of trimethyltriphenyl-phosphine-indium. These unprecedented metallophilic interactions have not been described for the lighter elements of group 13.

\section{Tetrel Bonds}

A tetrel bond [103] was defined as a noncovalent bond between any electron donating moiety and a LA atom belonging to Group 14 of elements. The initial investigations were basically theoretical; [104-110] however, experimental research on $\operatorname{TrB}$ has rapidly grown in the last decade. Actually, there are plenty of examples in the literature reporting experimental [111,112] investigations on tetrel bonding, which was named as such in 2013 [113-116]. A differential feature of tetrel bonding compared to halogen, chalcogen and pnictogen bonding interactions is that the charge density distribution on the tetrel atom is not anisotropic (absence of lone pairs). Moreover, it should be emphasized that the accessibility of the $\sigma$-holes is reduced in tetrels because they are located in the middle of three $\mathrm{sp}^{3}$-hybridized bonds. The behavior of carbon (also named carbon bonding in some studies) [111] is usually different because the rest of tetrels has a strong tendency to expand their valence. Indeed, the heavier tetrels tin and lead, which are commonly seen as metals, have rich coordination chemistry [117-120]. Furthermore, hypervalent species of silicon and germanium are very common [121-131]. Nevertheless, the heavier tetrel atoms $(\mathrm{Ge}-\mathrm{Pb})$ participate in noncovalent tetrel bonding interactions when they are in a chemical context avoiding hypervalency, see for instance the $\mathrm{SiO}_{12}(\mathrm{OH})_{8}$ cage in Figure 9 [132,133]. In fact, since the atomic polarizability increases in a given group of the periodic table on going from lighter to heavier elements, the stronger interactions in this group are expected for tin and lead [134-136].
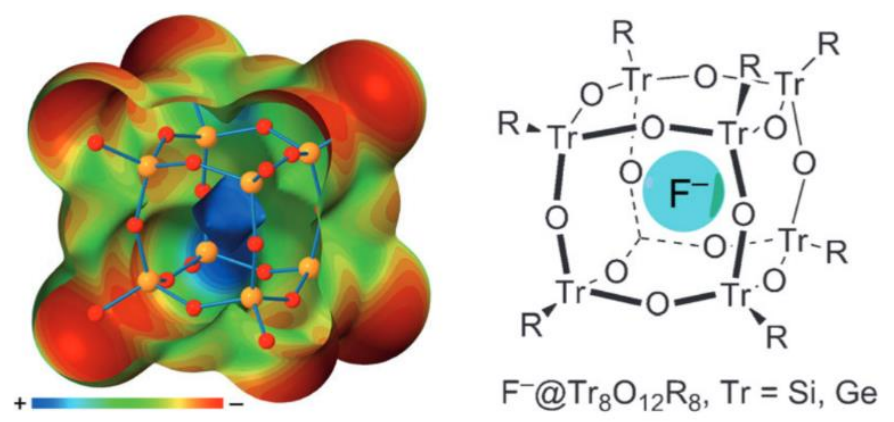

Figure 9. Left: Molecular electrostatic potential open surface of $\mathrm{SiO}_{12}(\mathrm{OH})_{8}$ cage. Right: A F $\mathrm{F}^{-}$ion encapsulated inside a $\operatorname{Tr}_{8} \mathrm{O}_{12} \mathrm{R}_{8}$ cage reported by Bauzá et al. [104].

For carbon, tetrel complex can also be understood as the start, $\left[\mathrm{A}: \cdots \mathrm{CR}_{3} \mathrm{~A}^{\prime}\right]$ or outcome, $\left[\mathrm{ATrR}_{3} \cdots: \mathrm{A}^{\prime}\right.$ ], of an $\mathrm{S}_{\mathrm{N}} 2$ nucleophilic attack [105] being the transition state an hypervalent specie. Most of the works on tetrel bonding focus on the heavier atoms leaving "carbon bonding" mostly unstudied. In an sp ${ }^{3}$ hybridized electron deficient $C$ atom, such as $\mathrm{CF}_{4}$, there is only a limited space available for the $\mathrm{LB}$ to interact with $\mathrm{C}$ due to its small size. In addition, $\mathrm{LB}$ gets very close to negative electrostatic potential of $\mathrm{F}$ in $\mathrm{CF}_{4}$. Frontera et al. [107] showed both theoretically and experimentally searching the $\mathrm{CSD}$ [77] that a convenient way to expose the $\sigma$-hole is to use cyclic $\mathrm{X}_{2} \mathrm{C}-\mathrm{CX}_{2}$ structures $(\mathrm{X}=\mathrm{F}, \mathrm{CN})$ where the accessibility of the $\sigma$-hole increases as the size of the cycle decreases. In fact, the $(\mathrm{CN})_{2} \mathrm{C}-\mathrm{C}(\mathrm{CN})_{2}$ motif was found to be highly directional in 1,1',2,2'-tetracyanocyclopropane/cyclobutane structures.

When $\mathrm{sp}^{2}$-hybridized electron deficient $\mathrm{C}$-atoms are considered ( $\pi$-hole instead of $\sigma$-hole), the accessibility is not a problem. In this sense, pioneering $\pi$-hole interactions were described in 1973 by Bürgi and Dunitz $[137,138]$ in a series of X-ray structural analyses disclosing the trajectory along a LB or nucleophile predominantly attacks the $\pi$-hole of a $\mathrm{C}=\mathrm{O}$. More than 20 years later, Egli and co-workers described the ability of guanosine to interact with the LBs (O-atom of de-oxiribose) and its importance in the stabilization of Z-DNA form [139]. 


\section{Pnictogen Bonds}

These bonds were first described in 2011 in three papers, one experimental [140] and two theoretical [141,142]. An authoritative review was published in a book by some of us (Chapter 8: J. E. Del Bene, I. Alkorta, J. Elguero, The Pnicogen Bond in Review: Structures, Binding Energies, Bonding Properties, and Spin-Spin Coupling Constants of Complexes Stabilized by Pnicogen Bonds, 191-264) [3,143], and another by Scheiner [144]. Although pnictogen bonds are, after halogen bonds, the most studied weak interaction, these bonds have been treated in a reduced number of books and reviews [103,143]. Grabowski classified them as tetrahedral Lewis acid centers [103]. Legon discussed these bonds in an article called " Tetrel, pnictogen and chalcogen bonds identified in the gas phase before they had names: a systematic look at noncovalent interactions" [57].

They are also called "pnicogen bonds" but the pnictogen name should prevail. Similar to halogen bond, pnictogen bond is also a noncovalent interaction. In pnictogen-bond complex, pnictogen atoms (Group VA elements) act as Lewis acid, which can accept electrons from electron donor groups.

Legon pointed out that tetrel, pnictogen, and chalcogen bonds were known in the gas phase (mainly by this author, using rotational spectroscopy) before they had names [56]. Recently, the gas-phase structure of a pnictogen-bonded compound was determined (Figure 10) [145].

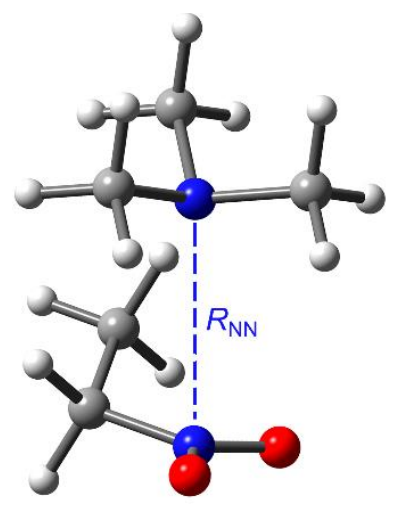

Figure 10. The nitromethane $\cdots$ trimethylamine pnictogen complex [145].

One of our main contributions to pnictogen bonds are the EOM/CCSD calculations, made by J. E. Del Bene, of ${ }^{31} \mathrm{P}$ coupling constants through the pnictogen bond, we called ${ }^{\mathrm{nP}} \mathrm{J}\left(\mathrm{X}_{-}{ }^{31} \mathrm{P}\right)[142]$. Of our papers concerning pnictogen bonds, we have selected the following eight ones [146-153]. Most of these papers were calculated at the MP2/aug'-cc-pVTZ basis set. We and others have found that $\mathrm{FPH}_{2}$ and related $\mathrm{YPH}_{2}\left(\mathrm{Y}=\mathrm{H}, \mathrm{OH}, \mathrm{OCH}_{3}, \mathrm{CH}_{3}, \mathrm{NH}_{2}\right)$ and $\mathrm{FH}_{2} \mathrm{X}(\mathrm{X}=\mathrm{P}, \mathrm{As})$ are strong and directional Lewis acid especially suited for theoretical studies [154-156]. Highly acidic heteroboranes yield strong pnictogen bonds [157].

$\mathrm{Li}, \mathrm{McDowell}$ et al. have shown that upon protonation, the binding distance of the pyridine-(4)- $\mathrm{PH}_{2} \cdots \mathrm{NH}_{3} \& \mathrm{PH}_{3}$ complexes becomes shorter and the interaction energy is more negative. This shows that the pnictogen bond is strengthened by the protonation of the $\mathrm{N}$ atom of pyridine [158]. $\mathrm{P} \cdots \pi$ and $\pi$-hole pnictogen bonds have been studied $[159,160]$ and the $\mathrm{Cl}_{3} \mathrm{P} \cdots \mathrm{C}_{6} \mathrm{H}_{6}$ complex studied experimentally by FTIR spectroscopy (Figure 11) [159]. Two important papers have been published, one on the catalysis by pnictogen bonds where there is a distinction between $\mathrm{PH}_{2} \mathrm{~F}$ $\sigma$-hole vs. $\mathrm{PO}_{2} \mathrm{~F} \pi$-hole [161], and the other of supramolecular structures using triple pnictogen bonds [162]. 


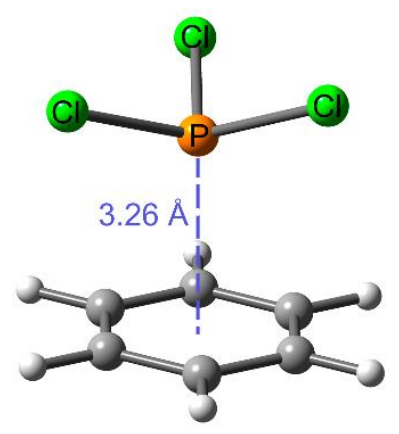

Figure 11. The $\mathrm{Cl}_{3} \mathrm{P} \cdots$ benzene complex [159].

Complexes $\mathrm{H}_{2} \mathrm{XP} \cdots \mathrm{NXH}_{2}\left(\mathrm{X}=\mathrm{H}, \mathrm{CH}_{3}, \mathrm{NH}_{2}, \mathrm{OH}, \mathrm{F}, \mathrm{Cl}\right)$ presenting $\mathrm{P} \cdots \mathrm{N}$ pnictogen bonds show stabilization energies between 8 and $39 \mathrm{~kJ} \cdot \mathrm{mol}^{-1}$ [146]. ${ }^{31} \mathrm{P}$ chemical shieldings and ${ }^{1 \mathrm{p}} J(\mathrm{~N}-\mathrm{P})$ SSCC across the pnictogen interaction were calculated. The last ones exhibit a quadratic dependence on the $\mathrm{N}-\mathrm{P}$ distance for complexes $\mathrm{H}_{2} \mathrm{XP} \cdots \mathrm{NXH}_{2}$, similar to the dependence of ${ }^{2 \mathrm{~h}} \mathrm{~J}(\mathrm{X}-\mathrm{Y})$ on the $\mathrm{X}-\mathrm{Y}$ distance for complexes with $\mathrm{X}-\mathrm{H} \cdots \mathrm{Y}$ hydrogen bonds.

The study the influence of $\mathrm{F}-\mathrm{H} \cdots$ F hydrogen bonds on the P $\cdots \mathrm{P}$ pnictogen bond in complexes $n \mathrm{FH} \cdots\left(\mathrm{PH}_{2} \mathrm{~F}\right)_{2}$ for $n=1-3$ shows that the formation of $\mathrm{F}-\mathrm{H} \cdots \mathrm{F}$ hydrogen bonds leads to a shortening of the $\mathrm{P}-\mathrm{P}$ distance, a lengthening of the $\mathrm{P}-\mathrm{F}$ distance involved in the hydrogen bond, a strengthening of the P..P interaction, and changes in atomic populations [147]. ${ }^{31} \mathrm{P}$ chemical shieldings, and ${ }^{1 \mathrm{P}} J$ $(\mathrm{P}-\mathrm{P})$ coupling constants were calculated.

Pnictogen-bonded cyclic trimers $\left(\mathrm{PH}_{2} \mathrm{X}\right)_{3}$ with $\mathrm{X}=\mathrm{F}, \mathrm{Cl}, \mathrm{OH}, \mathrm{NC}, \mathrm{CN}, \mathrm{CH}_{3}, \mathrm{H}$, and $\mathrm{BH}_{2}$ have been computed (Figure 12) [148]. Most of these complexes have $C_{3 h}$ symmetry and binding energies between -17 and $-63 \mathrm{~kJ} \cdot \mathrm{mol}^{-1}$. The NMR properties of chemical shielding and ${ }^{31} \mathrm{P}-{ }^{31} \mathrm{P}$ coupling constants have also been evaluated.

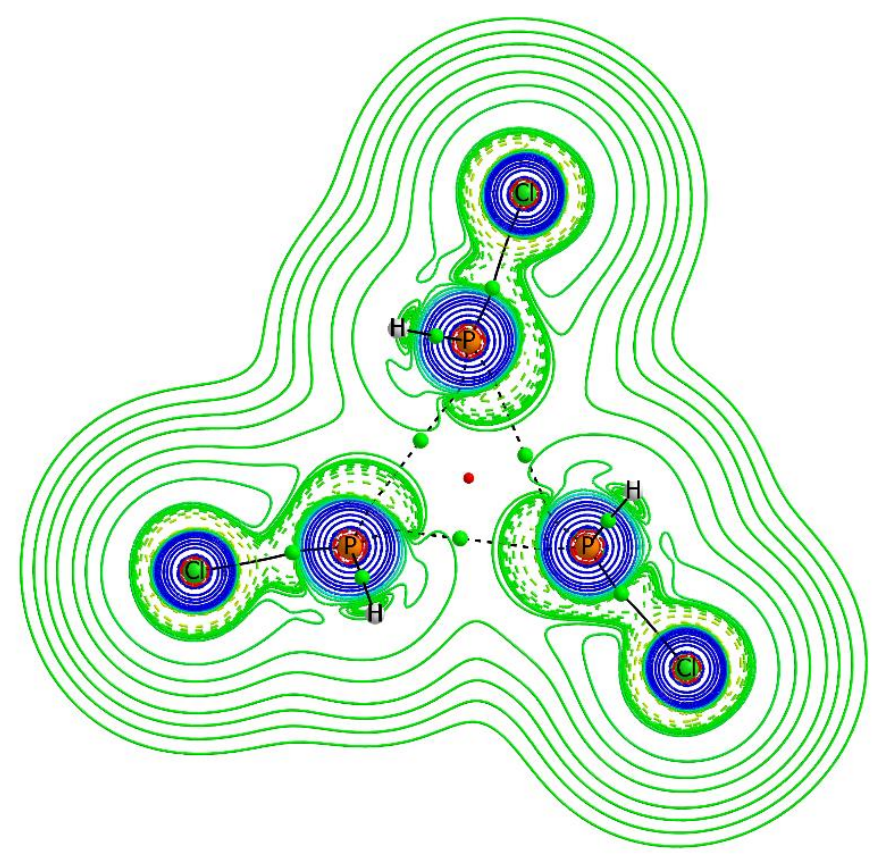

Figure 12. Laplacian of the electron density on the molecular plane of the trimer of $\left(\mathrm{PH}_{2} \mathrm{Cl}\right)[148]$.

Three papers have been reported comparative studies of different NCIs. In the first one [149]. the influence of substituent effects on the formation of $\mathrm{P} \cdots \mathrm{Cl}$ pnictogen bonds or halogen bonds was assessed. There, the potential energy surfaces $\mathrm{H}_{2} \mathrm{FP} \cdots \mathrm{ClY}$ for $\mathrm{Y}=\mathrm{F}, \mathrm{NC}, \mathrm{Cl}, \mathrm{CN}, \mathrm{CCH}, \mathrm{CH}_{3}$, and $\mathrm{H}$ were explored finding three different types of halogen-bonded complexes with traditional, 
chlorine-shared, and ion-pair bonds. Two different pnictogen-bonded complexes have also been found on these surfaces. In the second one [153], ab initio calculations were carried out in search of equilibrium dimers on $(\mathrm{XCP})_{2}$ potential energy surfaces, for $\mathrm{X}=\mathrm{CN}, \mathrm{Cl}, \mathrm{F}$, and $\mathrm{H}$. Five equilibrium dimers with $D_{\infty h}, C_{\infty v}, C_{s}, C_{2 h}$, and $C_{2}$ symmetries exist on the $(\mathrm{ClCP})_{2}$ potential energy surface, four on the $(\mathrm{FCP})_{2}$ and $(\mathrm{HCP})_{2}$ surfaces, and three on the $(\mathrm{NCCP})_{2}$ surface. These dimers are stabilized by traditional halogen, pnictogen, and tetrel bonds, and one of them by a hydrogen bond. Finally, Resnati et al. reported an example of a cocrystal where a pnictogen bond prevails over halogen and hydrogen bonds [163].

Another paper reported studies on $\mathrm{P}(\mathrm{V})$ complexes [150]. Pnictogen-bonded complexes $\mathrm{H}_{n} \mathrm{~F}_{5-n} \mathrm{P} \cdots \mathrm{N}$-Base, for $n=0-5$ were studied (two illustrative examples are given in Figure 13). The computed distances and $\mathrm{F}_{\mathrm{ax}}-\mathrm{P}-\mathrm{F}_{\mathrm{eq}}$ angles in complexes $\mathrm{F}_{5} \mathrm{P}: \mathrm{N}$-base are consistent with experimental CSD data [77]. All of the complexes with $\mathrm{PF}_{5}, \mathrm{PHF}_{4}, \mathrm{PH}_{4} \mathrm{~F}$, and $\mathrm{PH}_{5}$ have $\mathrm{C}_{4 v}$ symmetry, which is the same symmetry as that of the Berry transition structures of the monomers which lead to the exchange of axial and equatorial atoms.
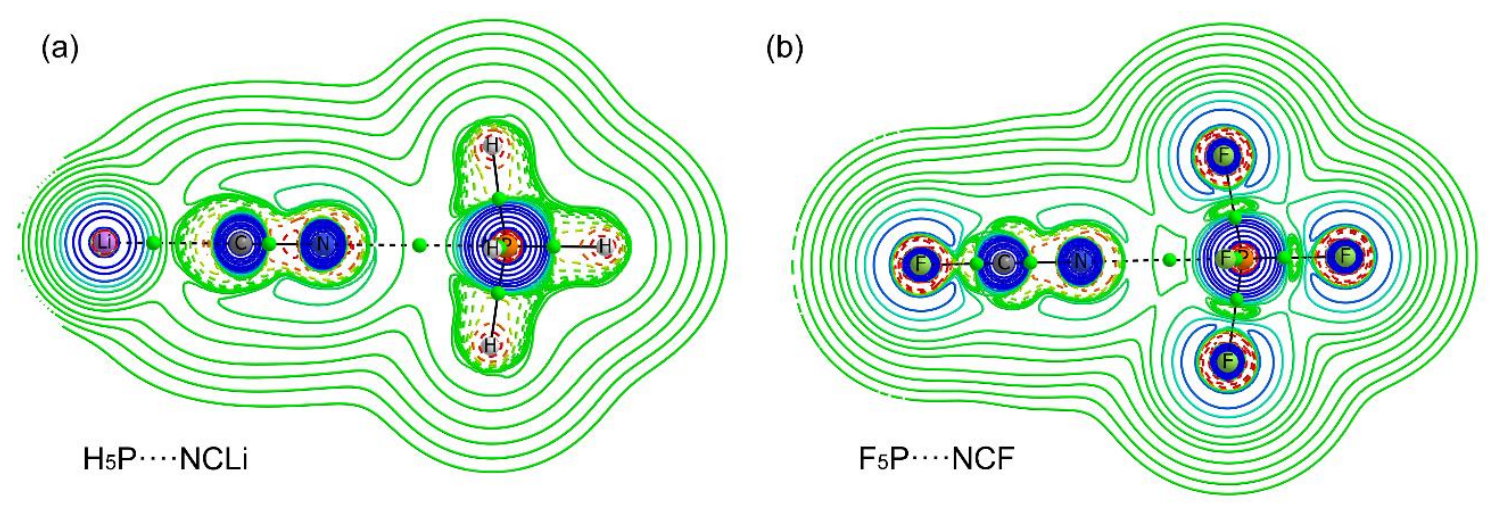

Figure 13. (a) Laplacian of the electron density on the molecular plane of $\mathrm{H}_{5} \mathrm{P} \cdots \mathrm{NCLi}$ complex; (b) $\mathrm{F}_{5} \mathrm{P} \cdots \mathrm{NCF}$ complex [150].

An ab initio study of the hydration process of metaphosphoric acid shows the importance of the pnictogen interactions [151]. This work was carried out at the MP2/6-31+G( $d, p)$ and MP2/aug-cc-pVTZ computational levels. Up to three explicit water molecules have been considered. The inclusion of more than one water molecule produces important cooperative effects and a shortening of the $\mathrm{O} \cdots \mathrm{P}$ pnictogen interaction simultaneously the reaction barrier drops about $50 \mathrm{~kJ} \mathrm{~mol}^{-1}$.

A general study of several kinds of NCIs was carried at the MP2/aug-cc-pVTZ computational level. In this paper [152], the dissociation energies $D_{e}$ of 250 complexes B $\cdots$ A composed of 11 Lewis bases $\mathrm{B}\left(\mathrm{N}_{2}, \mathrm{CO}, \mathrm{HC} \equiv \mathrm{CH}, \mathrm{CH}_{2}=\mathrm{CH}_{2}, \mathrm{C}_{3} \mathrm{H}_{6}, \mathrm{PH}_{3}, \mathrm{H}_{2} \mathrm{~S}, \mathrm{HCN}, \mathrm{H}_{2} \mathrm{O}, \mathrm{H}_{2} \mathrm{CO}\right.$, and $\left.\mathrm{NH}_{3}\right)$ and 23 Lewis acids ( $\mathrm{HF}, \mathrm{HCl}, \mathrm{HBr}, \mathrm{HC} \equiv \mathrm{CH}, \mathrm{HCN}, \mathrm{H}_{2} \mathrm{O}, \mathrm{F}_{2}, \mathrm{Cl}_{2}, \mathrm{Br}_{2}, \mathrm{ClF}, \mathrm{BrCl}, \mathrm{H}_{3} \mathrm{SiF}, \mathrm{H}_{3} \mathrm{GeF}, \mathrm{F}_{2} \mathrm{CO}, \mathrm{CO}_{2}, \mathrm{~N}_{2} \mathrm{O}$, $\mathrm{NO}_{2} \mathrm{~F}, \mathrm{PH}_{2} \mathrm{~F}, \mathrm{AsH}_{2} \mathrm{~F}, \mathrm{SO}_{2}, \mathrm{SeO}_{2}, \mathrm{SF}_{2}$, and $\mathrm{SeF}_{2}$ ) can be represented to good approximation by means of the equation $D_{e}=c^{\prime} N_{B} E_{A}$, in which $N_{B}$ is a numerical nucleophilicity assigned to $\mathrm{B}, E_{A}$ is a numerical electrophilicity assigned to $\mathrm{A}$, and $c^{\prime}$ is a constant, conveniently chosen to have the value $1.00 \mathrm{~kJ} \mathrm{~mol}^{-1}$. The 250 complexes were chosen to cover a wide range of noncovalent interaction types, namely: (1) the hydrogen bond; (2) the halogen bond; (3) the tetrel bond; (4) the pnictogen bond; and (5) the chalcogen bond.

Diederich orthogonal interactions $\left(\mathrm{N}: \cdots \mathrm{O}_{2} \mathrm{~N}\right)$ are pnictogen bonds when there is a nitrogen lone pair acting as the Lewis base and a nitrogen atom of the nitro group acting as the Lewis acid [164-166]. These interactions have been used by us [167-170] and by others to explain some experimental observations [171]. A theoretical paper entitled "Orthogonal interactions between nitryl derivatives and electron donors: pnictogen bonds"; in this paper complexes from nitryl derivatives $\left(\mathrm{NO}_{2} \mathrm{X}\right.$, $\mathrm{X}=\mathrm{CN}, \mathrm{F}, \mathrm{Cl}, \mathrm{Br}, \mathrm{NO}_{2}, \mathrm{OH}, \mathrm{CCH}$, and $\left.\mathrm{C}_{2} \mathrm{H}_{3}\right)$ and molecules acting as Lewis bases $\left(\mathrm{H}_{2} \mathrm{O}, \mathrm{H}_{3} \mathrm{~N}\right.$, 
$\mathrm{CO}, \mathrm{HCN}, \mathrm{HNC}$ and $\mathrm{HCCH}$ ) have been obtained at the MP2/aug-cc-pVTZ computational level; a search in the CSD database [77], was carried out, showing a large number of similar interactions in crystallographic structures.

\section{Chalcogen Bonds}

These bonds have received less attention than the pnictogen bonds, probably due to the fact that $\mathrm{P}$ is in chemistry and in biochemistry more important than $\mathrm{S}$. In addition, note that ${ }^{31} \mathrm{P}$ is a very good nucleus for NMR (spin 1/2, natural abundance 100\%) and ${ }^{33} \mathrm{~S}$ a "bad" one (spin 3/2, natural abundance $0.76 \%$ ). For books and reviews on chalcogen bonds, see [172-175].

The name "chalcogen bond" was introduced in 2009 by Wang, Ji and Zhang [176]. But papers discussing these NCIs were long known [177-181]. In particular, Gleiter et al. [181] investigated the intermolecular interactions between two molecules containing group 16 elements. The strength of this interaction increases steadily when going from $\mathrm{O}$ via $\mathrm{S}$ to $\mathrm{Se}$ and reaches its maximum for Te. Addition of electron-withdrawing substituents increases the strength of the bond. S...S contacts in thioamides have been studied both experimentally (charge densities) and theoretically [182].

Since most molecules have several kinds of atoms, and since all atoms can be Lewis acids, then, confronted with a Lewis base, several types of NCIs can be formed. For this reason, many papers have been devoted to the competition between some combination of hydrogen, alkaline-earth, tetrel, pnictogen, chalcogen, and halogen bonds [157,183-190]. Curiously, although the nature of the base can change the nature of the most stable acid, none of these publications reported an inversion of acidity. Huynh electronic parameter and its correlation with Hammett $\sigma$ constants were determined for neutral chalcogen donors [187].

More interesting are the papers reporting cooperative (augmentative) effects where a NCI is reinforced by another NCI, to the point to reach extraordinary values of gas-phase acidity or basicity [191,192].

Although most chalcogen bonds are related to intermolecular situations, a few correspond to intramolecular situations, e.g., to 1,8-disubstituted naphthalenes $[193,194]$. Other interesting topics related to chalcogen bonds are their use in chiral recognition [195], chalcogen-bonding catalysis [196], and the use by Diederich of benzo[c][1,2,5]thiadiazoles and benzo[c][1,2,5]telluradiazoles to build up capsule dimers [197], followed by a study of "2S-2N" squares formed by benzo[c][1,2,5]thiadiazoles [198].

\section{Halogen Bonds}

Halogen bonding is a $\sigma$-hole interaction of type $R-X \cdots: A(X=$ any element of group 17 including astatine [199]); that is currently experiencing a significant interest in the field of supramolecular chemistry [200-204]. It is the most directional interaction [205] of the $\sigma$-hole family, and it can be easily tuned by selecting the type of halogen atom involved $(\mathrm{X}=\mathrm{I}>\mathrm{Br}>\mathrm{Cl}>>\mathrm{F})[206,207]$ and nature of the substituent $R$. This tunability facilitates the rational design of X-bonded catalysts $[208,209]$ and supramolecular synthons to be utilized in crystal engineering [210-212]. The distribution of the electron density in a covalently bonded halogen atom is anisotropic. That is, it shows a region of positive electrostatic potential [213] along the extension of the covalent bond that confers it the ability to act as Lewis acid (i.e., halogen bond donor) [214]. Moreover, it also has a region of negative potential (negative belt) associated to the electron lone pairs conferring it the possibility to act as an electron-rich halogen bond acceptor (Lewis base) [215]. Recently, the X-Bond interaction was used in the field of molecular machines [216-218] providing a new dimension to this interaction. In addition, regarding its counterpart (Lewis base), it was recently demonstrated that transition metal complexes can act as halogen bond acceptors [219-221]. Clark [222,223] and Hobza [224,225] related the strength of halogen bonding to the so-called "polar flattening".

Several excellent reviews $[181,201,202,226]$ and books $[33,227]$ are available in the literature describing most aspects of halogen bonding; therefore, only some general features are commented 
herein briefly. Halogen bonding is comparable in strength [228] to the ubiquitous hydrogen bond, however, more sensitive to steric effects because the $\sigma$-hole is located in a small region of the van der Waals surface along the extension of the $\mathrm{R}-\mathrm{X}$ bond. A differentiating feature is that the H-bond can be only tuned varying the nature of $R$ and the halogen bond can be tuned varying both $R$ and $X$. The nature of the X-bond is still under discussion in the literature $[229,230]$. Note that most theoretical studies propose that an important contribution comes from the stabilization due to donor-acceptor orbital interactions. That is, a filled $\pi$ or $n$ orbital from the Lewis basic site donates electron density to the antibonding R-X sigma bond orbital [231-233]. Other important contributions are electrostatic effects, polarization in heavy halogens, and dispersion forces that depend upon on the nature of both the Lewis acid and Lewis base [234]. Finally, Kozuch and Martin used halogen bonds as benchmarks for theoretical analyses of wave methods and DFT methods [235].

\section{Aerogen Bonds}

A noble gas (or aerogen) [236] bond ( $\mathrm{NgB}$ ) was recently defined as: the interaction between an electron rich atom or group of atoms and any element of Group-18 acting as electron acceptor [237]. While reports on $\pi, \sigma$-hole interactions involving atoms of groups 14 to 17 as LA have exponentially grown in recent years, investigations on experimental aerogen bonding are scarce. One of those was reported by Schrobilgen's group [238], where they synthesized and X-ray characterized several xenon salts $\left[\mathrm{N}\left(\mathrm{C}_{2} \mathrm{H}_{5}\right)_{4}\right]_{3}\left[\mathrm{X}_{3}\left(\mathrm{XeO}_{3}\right)_{3}\right] \mathrm{X}=\mathrm{Cl}, \mathrm{Br}$. These salts form three aerogen bonding interactions with the halides by using the three $\sigma$-holes opposite to the $\mathrm{O}=\mathrm{Xe}$ bonds. Similar behavior was observed by Goettel et al. [239] in their investigation of a series of $\mathrm{XeO}_{3}$ adducts with nitriles since they also form three aerogen bonds in the solid state.

In Figure 14, two $\mathrm{X}$-ray structures are represented where the $\mathrm{XeO}_{3}$ establishes three concurrent aerogen bonds with pyridine $\mathrm{N}$-atoms [232]. These aerogen bonds are shorter for the $p$-dimethylaminopyridine Lewis base due to its stronger basicity compared to pyridine.

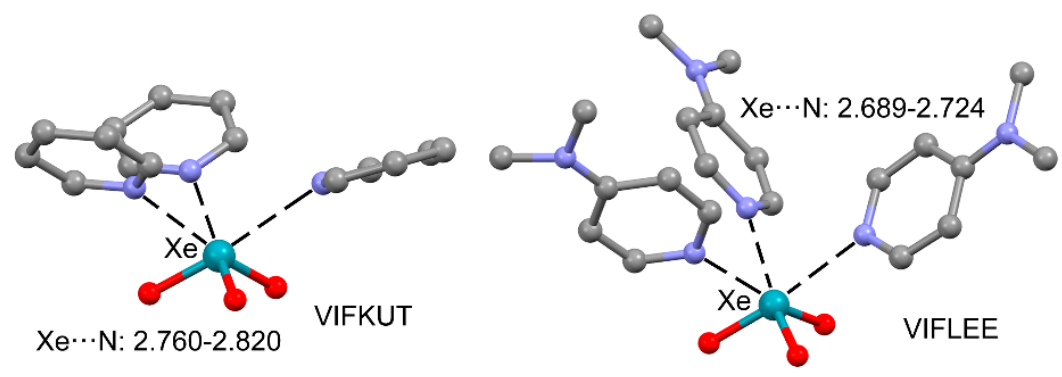

Figure 14. Aerogen bonging interactions in two $\mathrm{XeO}_{3}$ adducts (CSD refcodes VIFKUT and VIFLEE [77]).

Aerogen bonds are represented as black dashed lines.

Britvin et al. also demonstrated the tendency of xenon(VI) to form oxide structures synthesizing $\mathrm{K}_{4} \mathrm{Xe}_{3} \mathrm{O}_{12}$, an unprecedented perovskite based on xenon. Its importance is due to the fact that xenon is the only p-block element that forms perovskite frameworks by using a single cation $\left(\mathrm{K}^{+}\right)$. Remarkably, the authors showed that aerogen bonds are the NCIs that preserve the structural integrity of the perovskite. It is interesting to highlight that these compounds are explosive and the aerogen bonds have been proposed to be the trigger bonds responsible for the detonation $[240,241]$.

Several computational works studied this interaction energetically and geometrically, including its physical insights [242-253]. Interestingly, the effect of increasing the pressure (up to $50 \mathrm{GPa}$ ) on the aerogen interactions in $\mathrm{XeO}_{3}$ was also analyzed, resulting in O-hopping along the noncovalent $\mathrm{Xe}-\mathrm{O} \cdots$ Xe aerogen bonds, resembling H-hopping commonly observed in hydrogen bonds [254]. Moreover, cooperativity effects in aerogen bonding clusters were studied [255] and the interplay with other interactions, as well [256-259]. 


\section{Other Bonds}

Cation- $\pi$ and anion- $\pi$ (or lone pair- $\pi$ ) $[260,261]$ and even $\pi$ - $\pi$ stacking between a $\pi$-excessive and $\pi$-deficient aromatic rings (Figure 15) can be classified as LA/LB complexes (the Lewis acids being the cation and the hexafluorobenzene and the Lewis bases the anion, the lone pair and hexamethylbenzene) could be classified as tetrel bond since the carbon atoms act like LA (in the case of $\mathrm{C}^{+}$it depends on its nature, i.e., $\mathrm{C}=\mathrm{Na}$ should be an alkaline bond). However, we have decided not to force our systematization running against practices shared by the scientific community.

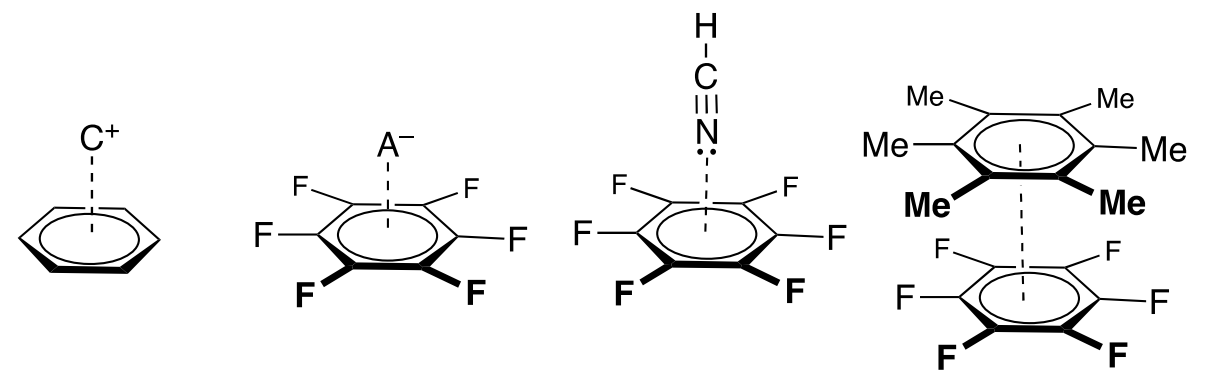

Figure 15. Cation- $\pi$, anion- $\pi$, lone pair $-\pi$ and $\pi-\pi$ stacking.

\section{Modeling}

The use of statistical methods to establish extra-thermodynamic relationships [262] for discussing values obtained by quantum methods presents the problem that they have no error, unlike experimental values; note that, without error, no statistical methods can be applied. In spite of this flaw, regression analysis is currently applied to values without error [263].

Two kinds of models are most commonly used: geometrical models like the Hammett, Taft, Grunwald-Winstein equations and the models subjacent to the HSAB (Hard Soft Acid Base)principle. Since we are dealing with Lewis acids and bases, it would be interesting to write a quantitative model that corresponds to hard-hard and soft-soft interactions being strong and hard-soft/soft-hard being weak. We are aware of Mayr et al. criticism of HSAB [264] but note a paper of 2002 by Chandrakumar and Pal entitled "A systematic study on the reactivity of Lewis acid-Base complexes through the local Hard-Soft Acid-Base principle" [265] where they succeed in calculating correctly the interaction energy of complexes using a HSAB model (not cited by Mayr in 2011). A quantitative version of the HSAB principle is Drago's ECW model [266,267].

Alkorta and Legon in two papers, which are (i) "Nucleophilicities of Lewis bases B and electrophilicities of Lewis acids A determined from the dissociation energies of complexes B $\cdots \mathrm{A}$ involving hydrogen bonds, tetrel bonds, pnictogen bonds, chalcogen bonds and halogen bonds" and (ii) "Noncovalent interactions involving alkaline-earth atoms and Lewis bases B: An ab initio investigation of beryllium and magnesium bonds, $\mathrm{B} \cdots \mathrm{MR}_{2}\left(\mathrm{M}=\mathrm{Be}\right.$ or $\mathrm{Mg}$, and $\mathrm{R}=\mathrm{H}$, $\mathrm{F}$ or $\left.\mathrm{CH}_{3}{ }^{\prime \prime}\right)$ use geometrical models to analyze $D_{\mathrm{e}}$ (equilibrium dissociation energies) in function of $k_{\sigma}$ (quadratic force constants) or NB (nucleophilicity of the Lewis base, B) plus $E_{\mathrm{A}}$ (electrophilicity of the Lewis acid): $D_{\mathrm{e}}=\mathrm{a}_{0}+$ $\mathrm{a}_{\mathrm{ij}} N_{\mathrm{B}} E_{\mathrm{A}}[53,152]$.

Steric effects are inexistent for protonation in the gas-phase due to the small size of the proton and appear in solution due to solvation, for example, by water molecules [268,269]. For HBs, steric effects have been found, but they are weak or inexistent [270-273]; on the other hand, steric effects are important in NCIs giving yield to a new concept, that of "Frustrated Lewis Pairs" (FLP) [274-278]. 


\section{Application Con Cahn-Ingold-Prelog Rules to Complexes Formed by Weak Interactions (Including Hydrogen Bonds)}

For all the situations where the Cahn-Ingold-Prelog priority rules apply for covalent and coordinative structures (ligancy four, axial, planar, ... ) [279,280], the priority rules also apply for noncovalent complexes [281,282]. This is particularly useful for crystal structures.

\section{A General Definition for Weak Interactions (Including HBs)}

A weak interaction between a Lewis acid and a Lewis base is established if the stabilizing forces (electrostatic, dipole-dipole, covalent, ... ) overcome the repulsion forces (steric). It is not necessary that the complex should be the lowest minimum; it suffices that there is a barrier between the complex and other minima of lower energy.

\section{Summary and Outlook}

The number and quality of recent references prove that NCIs are a topic of great and increasing interest. However, as the analysis of the authors of these references show, they belong to a reduced number of groups proving that NCIs are still not part of the large community of chemists. We hope this review will contribute to their diffusion and general acceptance.

A systematic naming resulting from identifying the interaction referring to the Group of the periodic table is very convenient for the sake of unambiguousness. Basically, all donor-acceptor noncovalent interactions can be identified by the element acting as the electrophile. This criterion has been already adopted by the IUPAC for the definition of hydrogen, halogen, and chalcogen bonds. This can be systematically applied to attractive interactions formed by the elements of Groups 1, 2, 10-18 and also to transition metals in a near future. Other names used in the literature like lithium bond, bromine bond or carbon bond can be considered sub-classes of alkali metal bond, halogen bond, and tetrel bond, respectively. Other interactions, like $\pi-\pi$ stacking, lp $-\pi$, or anion $-\pi$ interactions involving heteroaromatics, cannot be included in this systematic nomenclature. In contrast, the cation $-\pi$ interaction could be classified using this nomenclature by using the name of the group to which the cationic element belongs.

It can be predicted that more gas-phase MW structures will be determined in a not so-distant future. Organometallic chemists will report new structures of the regium and spodium classes. Other future developments will be attached to the biological importance of the NCIs.

Author Contributions: Conceptualization, I.A., A.F. and J.E.; methodology, I.A., A.F. and J.E.; validation, I.A., A.F. and J.E.; writing-original draft preparation, I.A., A.F. and J.E.; writing-review and editing, I.A., A.F. and J.E. All authors have read and agreed to the published version of the manuscript.

Funding: This work was carried out with financial support from the Ministerio de Ciencia, Innovación y Universidades of Spain (PGC2018-094644-B-C22) and Comunidad Autónoma de Madrid (P2018/EMT-4329 AIRTEC-CM). Thanks are also given to the CTI (CSIC) for their continued computational support. AF thanks the MICIU/AEI (project CTQ2017-85821-R FEDER funds) for financial support.

Acknowledgments: This is dedicated to Anthony C. Legon, pioneer of studies of noncovalent interactions.

Conflicts of Interest: The authors declare no conflict of interest.

\section{References}

1. Hobza, P.; Müller-Dethlefs, K. Noncovalent interactions. Theory and Experiment; RSC Theoretical and Computational Chemistry Series; Royal Society of Chemistry: Cambridge, UK, 2010.

2. Sauvage, J.P.; Gaspard, P. (Eds.) From Noncovalent Assemblies to Molecular Machines; Wiley-VCH: Weinheim, Germany, 2011.

3. Scheiner, S. (Ed.) Nonocovalent Forces; Springer: Cham, Switzerland, 2015.

4. Maharramov, A.M.; Mahmudov, K.T.; Kopylovich, M.N.; Pombeiro, A.J.L. (Eds.) Noncovalent Interactions in the Synthesis and Design of New Compounds; John and Wiley and Sons: Hoboken, NJ, USA, 2016. 
5. Mó, O. Some interesting features of the rich chemistry around electron-deficient systems. Pure Appl. Chem. 2019. [CrossRef]

6. Pimentel, G.C.; McClellan, A.L. The Hydrogen Bond; W.H. Freeman \& Co.: San Francisco, CA, USA, 1960.

7. Desiraju, G.R.; Steiner, T. The Weak Hydrogen Bond. In Structural Chemistry and Biology; International Union of Crystallography, Oxford Science Publications: Oxford, UK, 1999.

8. Gilli, G.; Gilli, P. The Nature of the Hydrogen Bond: Outline of a Comprehensive Hydrogen Bond Theory; International Union of Crystallography, Oxford Science Publications: Oxford, UK, 2009.

9. Grabowski, S.J.; Lesczcynski, J. (Eds.) Hydrogen Bonding—New Insights; Springer: Dordrecht, The Netherlands, 2006.

10. Li, Z.T.; Wu, L.Z. (Eds.) Hydrogen Bonded Supramolecular Structures; Springer: Berlin/Heidelberg, Germany, 2015.

11. Alkorta, I.; Rozas, I.; Elguero, J. Non-conventional hydrogen bonds. Chem. Soc. Rev. 1998, 27, $163-170$. [CrossRef]

12. Juanes, M.; Saragi, R.T.; Caminati, W.; Lesarri, A. The hydrogen bond and beyond: Perspectives for rotational investigations of non-covalent interactions. Chem. Eur. J. 2019, 25, 11402-11411. [CrossRef] [PubMed]

13. Alkorta, I.; Montero-Campillo, M.M.; Mó, O.; Elguero, J.; Yáñez, M. Weak interactions get strong: Synergy between tetrel and alkaline earth bonds. J. Phys. Chem. A 2019, 123, 7124-7132. [CrossRef] [PubMed]

14. Fürstner, A.; Davies, P.W. Catalytic carbophilic activation: Catalysis by platinum and gold $\pi$ acids. Angezw. Chem. Int. Ed. 2007, 46, 3410-3449. [CrossRef]

15. Lewis, G.N. Valence and the Structure of Atoms and Molecules; American Chemical Monograph Series; Chemical Catalogue Company: New York, NY, USA, 1923.

16. Jensen, W.B. The Lewis acid-base definitions: A status report. Chem. Rev. 1978, 78, 1-22. [CrossRef]

17. Politzer, P.; Murray, J.S.; Clark, T. Halogen bonding: An electrostatically-driven highly directional noncovalent interaction. Phys. Chem. Chem. Phys. 2010, 12, 7748-7757. [CrossRef]

18. Politzer, P.; Murray, J.S. Halogen bonding and other $\sigma$-hole interactions: A perspective. Phys. Chem. Chem. Phys. 2013, 15, 11178-11189. [CrossRef]

19. Bauzá, A.; Mooibroek, T.J.; Frontera, A. The bright future of unconventional $\sigma / \pi$-hole interactions. ChemPhysChem 2015, 16, 2496-2517.

20. Montero-Campillo, M.M.; Ferrer, M.; Mó, O.; Yáñez, M.; Alkorta, I.; Elguero, J. Insights into the bonding between electron-deficient elements. Systems with X-Y-X $(\mathrm{X}=\mathrm{B}, \mathrm{Al} ; \mathrm{Y}=\mathrm{Be}, \mathrm{Mg})$ bridges. Phys. Chem. Chem. Phys. 2020. submitted.

21. Ott, H.; Matthes, C.; Ringe, A.; Magull, J.; Stalke, D.; Klingebiel, U. On the track of novel triel-stabilized silylaminoiminoborenes. Chem. Eur. J. 2009, 15, 4602-4609. [CrossRef] [PubMed]

22. Wu, X.; Zhao, L.; Jin, J.; Pan, S.; Li, W.; Jin, X.; Wang, G.; Zhou, M.; Frenking, G. Observation of alkaline earth complexes $\mathrm{M}(\mathrm{CO})_{8}(\mathrm{M}=\mathrm{Ca}, \mathrm{Sr}$, or Ba) that mimic transition metals. Science 2018, 361, 912-916. [CrossRef] [PubMed]

23. Landis, C.R.; Hughes, R.P.; Weinhold, F. Comment on “Observation of alkaline earth complexes $\mathrm{M}(\mathrm{CO})_{8}(\mathrm{M}$ = Ca, Sr, or Ba) that mimic transition metals". Science 2019, 365, eaay2355. [CrossRef] [PubMed]

24. Zhao, L.; Pan, S.; Zhou, M.; Frenking, G. Response to comment on "Observation of alkaline earth complexes $\mathrm{M}(\mathrm{CO})_{8}(\mathrm{M}=\mathrm{Ca}, \mathrm{Sr}$, or Ba) that mimic transition metals". Science 2019, 365, eaay5021. [CrossRef]

25. Iwasaki, M.; Shichibu, Y.; Konishi, K. Unusual attractive Au- $\pi$ interactions in small diacetylene-modified gold clusters. Angew. Chem. Int. Ed. 2019, 58, 2443-2447. [CrossRef] [PubMed]

26. Frenking, G.; Shaik, S. (Eds.) The Chemical Bond, Chemical Bonding Across the Periodic Table; Wiley-VCH: Weinheim, Germany, 2014.

27. Brinck, T.; Borrfors, A.N. Electrostatic and polarization determine the strength of the halogen bond: A red card for charge transfer. J. Mol. Model. 2019, 25, 125. [CrossRef]

28. Wang, C.; Danovich, D.; Mo, Y.; Shaik, S. On the nature of the halogen bond. J. Chem. Theor. Comput. 2014, 10, 3726-3737. [CrossRef]

29. Mulliken, R.S. Structures of complexes formed by halogen molecules with aromatic and with oxygenated solvents. J. Am. Chem. Soc. 1950, 72, 600-608. [CrossRef]

30. Wang, C.; Guan, L.; Danovich, D.; Shaik, S.; Mo, Y. The origins of the directionality of noncovalent intermolecular interactions. J. Comput. Chem. 2016, 37, 34-45. [CrossRef]

31. Wang, H.; Wang, W.; Jin, W.J. $\sigma$-Hole vs $\pi$-hole bond: A comparison based on halogen bond. Chem. Rev. 2016, 116, 5072-5104. [CrossRef] 
32. Grabowski, S.J.; Sokalski, W.A. Are various -hole bonds steered by the same mechanism? ChemPhysChem 2017, 18, 1569-1577. [CrossRef] [PubMed]

33. Metrangolo, P.; Resnati, G. (Eds.) Halogen Bonding: Fundamentals and Applications. In Structure and Bonding; Springer: Berlin/Heidelberg, Germany, 2008; Volume 126.

34. Kollman, P.A.; Liebman, J.F.; Allen, L.C. The lithium bond. J. Am. Chem. Soc. 1970, 92, 1142-1150. [CrossRef]

35. Del Bene, J.E.; Alkorta, I.; Elguero, J. Characterizing complexes with F-Li $\cdots \mathrm{N}, \mathrm{H}-\mathrm{Li} \cdots \mathrm{N}$, and $\mathrm{CH}_{3} \mathrm{Li} \cdots \mathrm{N}$ lithium bonds: Structures, binding energies, and spin-spin coupling constants. J. Phys. Chem. A 2009, 113, 10327-10334. [CrossRef] [PubMed]

36. Esrafili, M.D.; Mohammadirad, N. Halogen bond interactions enhanced by sodium bonds-Theoretical evidence for cooperative and substitution effects in NCX $\cdots$ NCNa $\cdots$ NCY complexes $(X=F, C l, B r, I ; Y=H$, F, OH). Can. J. Chem. 2014, 92, 653-658. [CrossRef]

37. Solimannejad, M.; Rabbani, M.; Ahmadi, A.; Esrafili, M.D. Cooperative and diminutive interplay between the sodium bonding with hydrogen and dihydrogen bondings in ternary complexes of $\mathrm{NaC} 3 \mathrm{~N}$ with $\mathrm{HMgH}$ and HCN (HNC). Mol. Phys. 2014, 112, 2017-2022. [CrossRef]

38. Del Bene, J.E.; Alkorta, I.; Elguero, J. Characterizing complexes with F-Li ${ }^{+}-\mathrm{F}$ lithium bonds: Structures, binding energies, and spin-spin coupling constants. J. Phys. Chem. A 2009, 113, 8359-8365. [CrossRef]

39. Alkorta, I.; Elguero, J.; Provasi, P.F.; Pagola, G.I.; Ferraro, M.B. Electric field effects on nuclear magnetic resonance shielding of the 1.1 and 2:1 (homo and heterochiral) complexes of $\operatorname{XOOX}\left(\mathrm{X}, \mathrm{X}=\mathrm{H}, \mathrm{CH}_{3}\right)$ with lithium cation and their chiral discrimination. J. Chem. Phys. 2011, 135, 104116. [CrossRef]

40. Brea, O.; Alkorta, I.; Corral, I.; Mó, O.; Yáñez, M.; Elguero, J. Intramolecular Beryllium Bonds. Further Insights into Resonance Assistance Phenomena. In Intermolecular Interactions in Crystals; Novoa, J.J., Ed.; The Royal Society of Chemistry: London, UK, 2018; Chapter 15.

41. Montero-Campillo, M.M.; Mó, O.; Yáñez, M.; Alkorta, I.; Elguero, J. The beryllium bond. Adv. Inorg. Chem. 2019, 73, 73-121.

42. Yáñez, M.; Sanz, P.; Mó, O.; Alkorta, I.; Elguero, J. Beryllium bonds, do they exists? J. Chem. Theory Comput. 2009, 5, 2763-2771. [CrossRef]

43. Parameswaran, P.; Frenking, G. Chemical bonding in transition metal complexes with beryllium ligands $\left[\left(\mathrm{PMe}_{3}\right)_{2} \mathrm{M}-\mathrm{BeCl}_{2}\right],\left[\left(\mathrm{PMe}_{3}\right)_{2} \mathrm{M}-\mathrm{BeClMe}\right]$, and [(PMe $\left.\left.)_{2} \mathrm{M}-\mathrm{BeMe}_{2}\right](\mathrm{M}) \mathrm{Ni}, \mathrm{Pd}, \mathrm{Pt}\right)$. J. Phys. Chem. A 2010, 114, 8529-8535. [CrossRef]

44. Buchner, M.R. Recent contributions to the coordination chemistry of beryllium. Chem. Eur. J. 2019, 25, 12018-12036. [CrossRef] [PubMed]

45. Mó, O.; Yáñez, M.; Alkorta, I.; Elguero, J. Modulating the strength of hydrogen bonds through beryllium bonds. J. Chem. Theory Comput. 2012, 8, 2293-2300. [CrossRef] [PubMed]

46. Yáñez, M.; Mó, O.; Alkorta, I.; Elguero, J. Can conventional bases and unsaturated hydrocarbons be converted into gas-phase superacids that are stronger than most of the known oxyacids? The role of beryllium bonds. Chem. Eur. J. 2013, 19, 11637-11643. [CrossRef] [PubMed]

47. Brea, O.; Mó, O.; Yáñez, M.; Alkorta, I.; Elguero, J. Creating $\sigma$-holes through the formation of beryllium bonds. Chem. Eur. J. 2015, 21, 12676-12682. [CrossRef] [PubMed]

48. Brea, O.; Alkorta, I.; Mó, O.; Yáñez, M.; Elguero, J. Exergonic and spontaneous production of radicals through beryllium bonds. Angew. Chem. Int. Ed. 2016, 55, 8736-8739. [CrossRef] [PubMed]

49. Brea, O.; Corral, I.; Mó, O.; Yáñez, M.; Alkorta, I.; Elguero, J. Beryllium-based anion sponges: A close relatives of proton sponges. Chem. Eur. J. 2016, 22, 18322-18325. [CrossRef]

50. Yang, X.; Li, Q.; Cheng, J.; Li, W. A new interaction mechanism of $\mathrm{LiNH}_{2}$ with $\mathrm{MgH}_{2}$ : Magnesium bond. J. Mol. Model. 2013, 19, 247-253. [CrossRef]

51. Xu, H.L.; Li, Q.Z.; Scheiner, S. Effect of magnesium bond on the competition between hydrogen and halogen bonds and the induction of proton and halogen transfer. ChemPhysChem 2018, 19, 1456-1464. [CrossRef]

52. Sanz, P.; Montero-Campillo, M.M.; Mó, O.; Yáñez, M.; Alkorta, I.; Elguero, J. Intramolecular magnesium bonds in malonaldehyde-like systems: A critical view of the resonance-assisted phenomena. Theor. Chem. Acc. 2018, 137, 97. [CrossRef]

53. Alkorta, I.; Legon, A.C. Non-covalent interactions involving alkaline-earth atoms and Lewis bases B: An ab initio investigation of beryllium and magnesium bonds, $\mathrm{B} \cdots \mathrm{MR}_{2}\left(\mathrm{M}=\mathrm{Be}\right.$ or $\mathrm{Mg}$, and $\mathrm{R}=\mathrm{H}, \mathrm{F}$ or $\left.\mathrm{CH}_{3}\right)$. Inorganics 2019, 7, 35. [CrossRef] 
54. Montero-Campillo, M.M.; Sanz, P.; Mó, O.; Yáñez, M.; Alkorta, I.; Elguero, J. Alkaline-earth (Be, Mg and Ca) bonds at the origin of huge acidity enhancements. Phys. Chem. Chem. Phys. 2018, 20, 2413-2420. [CrossRef] [PubMed]

55. Frontera, A.; Bauzá, A. Regium- $\pi$ bonds: An unexplored link between noble metal nanoparticles and aromatic surfaces. Chem. Eur. J. 2018, 24, 7228-7234. [CrossRef] [PubMed]

56. Legon, A.C.; Walker, N.R. What's in a name? 'Coinage-metal' non-covalent bonds and their definition. Tetrel, pnictogen and chalcogen bonds identified in the gas phase before they had names: A systematic look at non-covalent interactions. Phys. Chem. Chem. Phys. 2018, 20, 19332-19338. [CrossRef] [PubMed]

57. Legon, A.C.; Walker, N.R. Tetrel, pnictogen and chalcogen bonds identified in the gas phase before they had names: A systematic look at non-covalent interactions. Phys. Chem. Chem. Phys. 2017, 19, 14884-14896. [CrossRef] [PubMed]

58. Stenlid, J.H.; Johansson, A.J.; Brinck, T. $\sigma$-Holes and $\sigma$-lumps direct the Lewis basic and acidic interactions of noble metal nanoparticles: Introducing regium bonds. Phys. Chem. Chem. Phys. 2018, 20, 2676-2692. [CrossRef] [PubMed]

59. Li, H.; Li, Q.; Li, R.; Li, W.; Cheng, J. Prediction and characterization of $\mathrm{HCCH} \cdots \mathrm{AuX}(\mathrm{X}=\mathrm{OH}, \mathrm{F}, \mathrm{Cl}, \mathrm{Br}$, $\mathrm{CH}_{3}, \mathrm{CCH}, \mathrm{CN}$ and $\mathrm{NC}$ ) complexes: A $\pi$ Au-bond. J. Chem. Phys. 2011, 135, 074304. [CrossRef] [PubMed]

60. Zierkiewicz, W.; Michalczyk, M.; Wysokinski, R.; Scheiner, S. Dual geometry schemes in tetrel bonds: Complexes between $\mathrm{TF}_{4}(\mathrm{~T}=\mathrm{Si}, \mathrm{Ge}, \mathrm{Sn})$ and pyridine derivatives. Molecules 2019, 24, 376. [CrossRef]

61. Stenlid, J.H.; Johansson, A.J.; Brinck, T. $\sigma$-Holes on transition metal nanoclusters and their influence on the local Lewis acidity. Crystals 2017, 7, 222. [CrossRef]

62. Brinck, T.; Stenlid, J.H. The Molecular Surface Property Approach: A Guide to Chemical Interactions in Chemistry, Medicine, and Material Science. Adv. Theor. Simul. 2019, 2, 1800139. [CrossRef]

63. Pérez-Bitrián, A.; Baya, M.; Casas, J.M.; Falvello, L.R.; Martín, A.; Menjón, B. $\left(\mathrm{CF}_{3}\right)_{3} \mathrm{Au}$ as a highly acidic organogold(III) fragment. Chem. Eur. J. 2017, 23, 14918-14930. [CrossRef]

64. Martín-Somer, A.; Montero-Campiño, M.M.; Mó, O.; Yáñez, M.; Alkorta, I.; Elguero, J. Some interesting features of non-covalent interactions. Croat. Chim. Acta 2014, 87, 291-396. [CrossRef]

65. Sánchez-Sanz, G.; Trujillo, C.; Alkorta, I.; Elguero, J. Understanding regium bonds and their competition with hydrogen bonds in $\mathrm{Au}_{2}: \mathrm{HX}$ complexes. ChemPhysChem 2019, 20, 1572-1580. [CrossRef] [PubMed]

66. Zhang, J.; Wang, Z.; Liu, S.; Cheng, J.; Li, W.; Li, Q. Synergistic and diminutive effects between triel bond and regium bond: Attractive interactions between $\pi$-hole and $\sigma$-hole. Appl. Organomet. Chem. 2019, 33, e4806. [CrossRef]

67. Terrón, A.; Buils, J.; Mooibroek, T.J.; Barceló-Oliver, M.; García-Raso, A.; Fiol, J.J.; Frontera, A. Synthesis, $\mathrm{X}$-ray characterization and regium bonding interactions of a trichlorido-(1-hexylcytosine)gold(III) complex. Chem. Commun. 2020. [CrossRef] [PubMed]

68. Zheng, B.; Liu, Y.; Wang, Z.; Zhou, F.; Liu, Y.; Ding, X.; Lu, T. Regium bonds formed by MX (M = Cu, $\mathrm{Ag}, \mathrm{Au} ; \mathrm{X}=\mathrm{F}, \mathrm{Cl}, \mathrm{Br}$ ) with phosphine-oxide/phosphinous acid: Comparisons between oxygen-shared and phosphine-shared complexes. Mol. Phys. 2019, 117, 2443-2455. [CrossRef]

69. Trujillo, C.; Sánchez-Sanz, G.; Elguero, J.; Alkorta, I. The Lewis Acidities of Gold(I) and Gold(III): A Theoretical Study of Complexes of $\mathrm{AuCl}$ and $\mathrm{AuCl}_{3}$. Organometallics 2020. submitted.

70. Patil, N.T.; Yamamoto, Y. Gold-catalyzed reactions of oxo-alkynes. Arkivoc 2007, 6, 19.

71. Yamamoto, Y. From $\sigma$ - to $\pi$-electrophilic Lewis acids. Application to selective organic transforma-tions. J. Org. Chem. 2007, 21, 7817-7831. [CrossRef]

72. Yamamoto, Y.; Gridnev, I.D.; Patil, N.T.; Jin, T. Alkyne activation with Brønsted acids, iodine, or gold complexes, and its fate leading to synthetic application. Chem. Commun. 2009, 5075-5087. [CrossRef]

73. Bauzá, A.; Frontera, A. Regium $-\pi$ vs. cation $-\pi$ interactions in $\mathrm{M}_{2}$ and $\mathrm{MCl}(\mathrm{M}=\mathrm{Cu}, \mathrm{Ag}$ and $\mathrm{Au})$ complexes with small aromatic systems: An ab initio study. Inorganics 2018, 6, 64. [CrossRef]

74. Lu, P.; Boorman, T.C.; Slawin, A.M.Z.; Larrosa, I. Gold(I)-mediated C-H activation of arenes. J. Am. Chem. Soc. 2010, 132, 5580-5581. [CrossRef] [PubMed]

75. Radenkovic, S.; Antic, M.; Savic, N.D.; Glisic, B.D. The nature of the Au-N bond in gold(III) complexes with aromatic nitrogen-containing heterocycles: The influence of $\mathrm{Au}(\mathrm{III})$ ions on the ligand aromaticity. New J. Chem. 2017, 41, 12407-12415. [CrossRef]

76. Joy, J.; Jemmis, E.D. Contrasting Behavior of the Z Bonds in X-Z $\cdots Y$ Weak Interactions: Z = Main Group Elements Versus the Transition Metals. Inorg. Chem. 2017, 56, 1132-1143. [CrossRef] [PubMed] 
77. CSD: Allen, F.H. The Cambridge Structural Database: A quarter of a million crystal structures and rising, Acta Crystallogr. Sect. B 2002, 58, 380-388.

78. Chieh, C. Synthesis and structure of dichlorobis(thiosemicarbazide)mercury(II). Can. J. Chem. 1977, 55, 1583-1587. [CrossRef]

79. Lupinetti, A.J.; Jonas, V.; Thiel, W.; Strauss, S.H.; Frenking, G. Trends in molecular geometries and bond strengths of the homoleptic $\mathrm{d}^{10}$ metal carbonyl cations $\left[\mathrm{M}(\mathrm{CO})_{n}\right]^{\mathrm{x}+}\left(\mathrm{M}^{\mathrm{x}+}=\mathrm{Cu}^{+}, \mathrm{Ag}^{+}, \mathrm{Au}^{+}, \mathrm{Zn}^{2+}, \mathrm{Cd}^{2+}\right.$, $\left.\mathrm{Hg}^{2+} ; n=1-6\right)$ : A theoretical study. Chem. Eur. J. 1999, 5, 2573-2583. [CrossRef]

80. Wang, S.R.; Arrowsmith, M.; Braunschweig, H.; Dewhurst, R.D.; Dömling, M.; Mattock, J.D.; Pranckevicius, C.; Vargas, A. Monomeric 16-electron $\pi$-diborene complexes of $\mathrm{Zn}(\mathrm{II})$ and $\mathrm{Cd}(\mathrm{II})$. J. Am. Chem. Soc. 2017, 139, 10661-10664. [CrossRef]

81. Grabowski, S.J. Boron and other triel Lewis acid centers: From hypovalency to hypervalency. ChemPhysChem. 2014, 15, 2985-2993. [CrossRef]

82. Hiberty, P.C.; Ohanessian, G. Comparison of minimal and extended basis sets in terms of resonant formulas. Application to 1, 3-dipoles. J. Am. Chem. Soc. 1982, 104, 66-70. [CrossRef]

83. Brinck, T.; Murray, J.S.; Politzer, P. A computational analysis of the bonding in boron trichloride and their complexes with ammonia. Inorg. Chem. 1993, 32, 2622-2625. [CrossRef]

84. Kutzelnigg, W. Chemical bonding in higher main group elements. Angew. Chem. Int. Ed. 1984, 23, $272-295$. [CrossRef]

85. Rowsell, B.D.; Gillespie, R.J.; Heard, G.L. Ligand close-packing and the Lewis acidity of BF3 and BC3. Inorg. Chem. 1999, 38, 4659-4662. [CrossRef] [PubMed]

86. Bessac, F.; Frenking, $\mathrm{G}$. Why is $\mathrm{BCl}_{3}$ a stronger Lewis acid with respect to strong bases than $\mathrm{BF}_{3}$ ? Inorg. Chem. 2003, 42, 7990-7994. [CrossRef] [PubMed]

87. Fau, S.; Frenking, G. Theoretical investigation of the weakly bonded donor-acceptor complexes $\mathrm{H}_{3} \mathrm{~B}-\mathrm{H}_{2}$, $\mathrm{X}_{3} \mathrm{~B}_{-} \mathrm{C}_{3} \mathrm{H}_{4}$, and $\mathrm{X}_{3} \mathrm{~B}-\mathrm{C}_{2} \mathrm{H}_{2}(\mathrm{X}=\mathrm{H}, \mathrm{F}, \mathrm{Cl})$. Mol. Phys. 1999, 96, 519-527.

88. Grabowski, S.J. $\pi$-Hole bonds: Boron and aluminum Lewis acid centers. ChemPhysChem 2015, 16, 1470-1479. [CrossRef]

89. Bauzá, A.; Frontera, A. On the versatility of $\mathrm{BH}_{2} \mathrm{X}(\mathrm{X}=\mathrm{F}, \mathrm{Cl}, \mathrm{Br}$, and I) compounds as halogen-, hydrogen-, and triel-bond donors: An ab initio study. ChemPhysChem 2016, 17, 3181-3186. [CrossRef]

90. Bauzá, A.; García-Llinás, X.; Frontera, A. Charge-assisted triel bonding interactions in solid state chemistry: A combined computational and crystallographic study. Chem. Phys. Lett. 2016, 666, 73-78. [CrossRef]

91. Gao, L.; Zeng, Y.; Zhang, X.; Meng, L. Comparative studies on group III $\sigma$-hole and $\pi$-hole interactions. J. Comput. Chem. 2016, 37, 1321-1327. [CrossRef]

92. Bauzá, A.; Frontera, A. Competition between lone pair- $\pi$, halogen- $\pi$ and triel bonding interactions involving $\mathrm{BX}_{3}(\mathrm{X}=\mathrm{F}, \mathrm{Cl}, \mathrm{Br}$ and I) compounds: An ab initio study. Theor. Chem. Acc. 2017, 136, 37. [CrossRef]

93. Chi, Z.; Li, Q.; Li, H.B. Comparison of triel bonds with different chalcogen electron donors: Its dependence on triel donor and methyl substitution. Int. J. Quant. Chem. 2019, 120, e26046. [CrossRef]

94. Leopold, K.R.; Canagaratna, M.; Phillips, J.A. Partially Bonded Molecules from the Solid State to the Stratosphere. Acc. Chem. Res. 1997, 30, 57-64. [CrossRef]

95. Phillips, J.; Giesen, D.; Wells, N.; Halfen, J.; Knutson, C.; Wrass, J. Condensed-phase effects on the structural properties of $\mathrm{C}_{6} \mathrm{H}_{5} \mathrm{CN}-\mathrm{BF}_{3}$ and $\left(\mathrm{CH}_{3}\right)_{3} \mathrm{CCN}_{-} \mathrm{BF}_{3}$ : IR spectra, crystallography, and computations. J. Phys. Chem. A 2005, 109, 8199-8208. [CrossRef] [PubMed]

96. Fiacco, D.; Leopold, K. Partially bound systems as sensitive probes of microsolvation: A microwave and ab initio study of HCN $\cdots \mathrm{HCN}_{\mathrm{B}}$. J. Phys. Chem. A 2003, 107, 2808-2814. [CrossRef]

97. Tang, Q.J.; Li, Q.Z. Abnormal synergistic effects between Lewis acid-base interaction and halogen bond in $\mathrm{F}_{3}$ B $\cdots$ NCX $\cdots$ NCM. Mol. Phys. 2015, 113, 3809-3814. [CrossRef]

98. Zhang, J.R.; Li, W.Z.; Cheng, J.B.; Liu, Z.B.; Li, Q.Z. Cooperative effects between $\pi$-hole triel and $\pi$-hole chalcogen bonds. RSC Adv. 2018, 8, 26580-26588. [CrossRef]

99. Liu, M.X.; Zhuo, H.Y.; Li, Q.Z.; Li, W.Z.; Cheng, J.B. Theoretical study of the cooperative effects between the triel bond and the pnicogen bond in $\mathrm{BF}_{3} \cdots \mathrm{NCXH}_{2} \cdots \mathrm{Y}\left(\mathrm{X}=\mathrm{P}, \mathrm{As}, \mathrm{Sb} ; \mathrm{Y}=\mathrm{H}_{2} \mathrm{O}, \mathrm{NH}_{3}\right)$ complexes. J. Mol. Model. 2016, 22, 10. [CrossRef]

100. Yourdkhani, S.; Korona, T.; Hadipour, N.L. Interplay between tetrel and triel bonds in $\mathrm{RC}_{6} \mathrm{H}_{4} \mathrm{CN} \cdots \mathrm{MF}_{3} \mathrm{CN} \cdots \mathrm{BX}_{3}$ complexes: A combined symmetry-adapted perturbation theory, Møller-Plesset, and Quantum Theory of Atoms-in-Molecules study. J. Comput. Chem. 2015, 36, 2412-2428. [CrossRef] 
101. Echeverría, J. In(III) ‥ In(III) short contacts: An unnoticed metallophilic interaction? Chem. Commun. 2018, 54, 6312-6315. [CrossRef]

102. Echeverría, J. Intermolecular carbonyl -. carbonyl interactions in transition-metal complexes. Inorg. Chem. 2018, 57, 5429-5437. [CrossRef]

103. Grabowski, S.J. Pnicogan and tetrel bonds-Tetrahedral Lewis acid centers. Struct. Chem. 2019, 30, 1141-1152. [CrossRef]

104. Bauzá, A.; Mooibroek, T.J.; Frontera, A. Tetrel bonding interactions. Chem. Rec. 2016, 16, 473-487. [CrossRef] [PubMed]

105. Grabowski, S.J. Tetrel bond- $\sigma$-hole as a preliminary stage of the $\mathrm{S}_{\mathrm{N}} 2$ reaction. Phys. Chem. Chem. Phys. 2014, 16, 1824-1834. [CrossRef] [PubMed]

106. Bauzá, A.; Ramis, R.; Frontera, A. Computational study of anion recognition based on tetrel and hydrogen bonding interaction by calix[4]pyrrole derivatives. Comput. Theor. Chem. 2014, 1038, 67-70. [CrossRef]

107. Bauzá, A.; Mooibroek, T.J.; Frontera, A. Small cycloalkane $(\mathrm{CN})_{2} \mathrm{C}-\mathrm{C}(\mathrm{CN})_{2}$ structures are highly directional non-covalent carbon-bond donors. Chem. Eur. J. 2014, 20, 10245-10248. [CrossRef]

108. Bauzá, A.; Mooibroek, T.J.; Frontera, A. Tetrel-bonding interaction: Rediscovered supramolecular force? Angew. Chem. Int. Ed. 2013, 52, 12317-12321. [CrossRef]

109. Mani, D.; Arunan, E. The $\mathrm{X}-\mathrm{C} \cdots \mathrm{Y}(\mathrm{X}=\mathrm{O} / \mathrm{F}, \mathrm{Y}=\mathrm{O} / \mathrm{S} / \mathrm{F} / \mathrm{Cl} / \mathrm{Br} / \mathrm{N} / \mathrm{P})$ 'carbon bond' and hydrophobic interactions. Phys. Chem. Chem. Phys. 2013, 15, 14377-14383. [CrossRef]

110. Naseer, M.M.; Hussain, M.; Bauzá, A.; Lo, K.M.; Frontera, A. Intramolecular noncovalent carbon bonding interaction stabilizes the cis conformation in acylhydrazones. ChemPlusChem 2018, 83, 881-885. [CrossRef]

111. Thomas, S.P.; Pavan, M.S.; Guru Row, T.N. Experimental evidence for 'carbon bonding' in the solid state from charge density analysis. Chem. Commun. 2014, 50, 49-51. [CrossRef]

112. Mirdya, S.; Frontera, A.; Chattopadhyay, S. Formation of a tetranuclear supramolecule via non-covalent $\mathrm{Pb} \cdots \mathrm{Cl}$ tetrel bonding interaction in a hemidirected lead(II) complex with a nickel(II) containing metaloligand. CrystEngComm. 2019, 21, 6859-6868. [CrossRef]

113. Sohail, M.; Panisch, R.; Bowden, A.; Bassindale, A.R.; Taylor, P.G.; Korlyukov, A.A.; Arkhipov, D.E.; Male, L.; Callear, S.; Coles, S.J.; et al. Pentacoordinate silicon complexes with dynamic motion resembling a pendulum on the SN2 reaction pathway. Dalton. Trans. 2013, 42, 10971-10981. [CrossRef]

114. Mikosch, J.; Trippel, S.; Eichhorn, C.; Otto, R.; Lourderaj, U.; Zhang, J.X.; Hase, W.L.; Weidemüller, M.; Wester, R. Imaging Nucleophilic Substitution Dynamics. Science 2008, 319, 183-186. [CrossRef] [PubMed]

115. Langer, J.; Matejcik, S.; Illenberger, E. The nucleophilic displacement $\left(\mathrm{S}_{\mathrm{N}} 2\right)$ reaction $\mathrm{F}^{-}+\mathrm{CH}_{3} \mathrm{Cl} \rightarrow \mathrm{CH}_{3} \mathrm{~F}+$ $\mathrm{Cl}^{-}$induced by resonant electron capture in gas phase clusters. Phys. Chem. Chem. Phys. 2000, 2, 1001-1005. [CrossRef]

116. Levy, C.J.; Puddephatt, R.J. Rapid reversible oxidative addition of group 14-halide bonds to platinum (II): rates, equilibria, and bond energies. J. Am. Chem. Soc. 1997, 119, 10127-10136. [CrossRef]

117. The Chemistry of Functional Groups. The Chemistry of Organic Germanium, Tin and Lead Compounds; Patai, S., Rappoport, Z., Eds.; John and Wiley and Sons: Hoboken, NJ, USA, 1995; Volume 19.

118. Parr, J. Comprehensive Coordination Chem. II; McCleverty, J.A., Meyer, T.J., Eds.; Pergamon Press: Oxford, UK, 2004; Volume 3, p. 545.

119. Sato, T. Comprehensive Organometallic Chem. II; Abel, E.W., Stone, F.G.A., Wilkinson, G., Eds.; Pergamon Press: Oxford, UK, 1995; Volume 11, p. 389.

120. Pinhey, J.T. Comprehensive Organometallic Chem. II; Abel, E.W., Stone, F.G.A., Wilkinson, G., Eds.; Pergamon Press: Oxford, UK, 1995; Volume 11, p. 461.

121. Greenberg, A.; Wu, G. Structural relationships in silatrane molecules. Struct. Chem. 1990, 1, 79-85. [CrossRef]

122. Hencsei, P. Evaluation of silatrane structures by correlation relationships. Struct. Chem. 1991, 2, 21-26. [CrossRef]

123. Voronkov, M.G.; Barishok, V.P.; Petukhov, L.P.; Rahklin, R.G.; Pestunovich, V.A. 1-Halosilatranes. J. Organomet. Chem. 1988, 358, 39-55. [CrossRef]

124. Lukevics, E.; Dimens, V.; Pokrovska, N.; Zicmane, I.; Popelis, J.; Kemme, A. Addition of nitrile oxides to 2,3-dihydrofurylsilanes. Crystal and molecular structure of tetrahydrofuro [2,3- $d]$-isoxazolylsilanes. $J$. Organomet. Chem. 1999, 586, 200-207. [CrossRef]

125. Corriu, R.J.P. Hypervalent species of silicon: Structure and reactivity. J. Organomet. Chem. 1990, 400, 81-106. [CrossRef] 
126. Förgács, G.; Kolonits, M.; Hargittai, I. The gas-phase molecular structure of 1-fluorosilane from electron diffraction. Struct. Chem. 1990, 1, 245-250. [CrossRef]

127. Eujen, R.; Petrauskas, E.; Roth, A.; Brauer, D.J. The structures of 1-chlorogermatrane and of 1-fluorogermatrane, revisited. J. Organomet. Chem. 2000, 613, 86-92. [CrossRef]

128. Lukevics, E.; Ignatovich, L.; Beliakov, S. Synthesis and molecular structure of phenyl and tolylgermatranes. J. Organomet. Chem. 1999, 588, 222-230. [CrossRef]

129. Livant, P.; Northcott, J.; Webb, T.R. Structure of an oxo-bridged germatrane dimer. J. Organomet. Chem. 2001, 620, 133-138. [CrossRef]

130. Karlov, S.S.; Shutov, P.L.; Churakov, A.V.; Lorberth, J.; Zaitseva, G.S. New approach to 1-(phenylethynyl) germatranes and 1-(phenylethynyl)-3,7,10-trimethylgermatrane. Reactions of 1-(phenylethynyl) germatrane with $N$-bromosuccinimide and bromine. J. Organomet. Chem. 2001, 627, 1-5. [CrossRef]

131. Shen, Q.; Hilderbrandt, R.L. The structure of methyl silatrane (1-methyl-2,8,9-trioxa-5-aza-1-silabicyclo(3.3.3)undecane) as determined by gas phase electron diffraction. J. Mol. Struct. 1980, 64, 257-262. [CrossRef]

132. Scilabra, P.; Kumar, V.; Ursini, M.; Resnati, G. Close contacts involving germanium and tin in crystal structures: Experimental evidence of tetrel bonds. J. Mol. Model. 2018, 24, 37. [CrossRef]

133. Frontera, A.; Bauzá, A. S...Sn tetrel bonds in the activation of peroxisome proliferator-activated receptors (PPARs) by organotin molecules. Chem. Eur. J. 2018, 24, 16582-16587. [CrossRef]

134. Southern, S.A.; Errulat, D.; Frost, J.; Gabidullin, B.; Bryce, D.L. Prospects for ${ }^{207} \mathrm{~Pb}$ solid-state NMR studies of lead terel bonds. Faraday Discuss. 2017, 203, 165-186. [CrossRef]

135. Mahmoudi, G.; Bauzá, A.; Amini, M.; Molins, E.; Mague, J.T.; Frontera, A. On the importance of tetrel bonding interactions in lead (II) complexes with (iso) nicotinohydrazide based ligands and several anions. Dalton Trans. 2016, 45, 10708-10716. [CrossRef]

136. Servati Gargari, M.; Stilinović, V.; Bauzá, A.; Frontera, A.; McArdle, P.; van Derveer, D.; Ng, S.W.; Mahmoudi, G. Design of lead(II) metal-organic frameworks based on covalent and tetrel bonding. Chem. Eur. J. 2015, 21, 17951-17958. [CrossRef]

137. Burgi, H.B. Chemical reaction coordinates from crystal structure data. I. Inorg. Chem. 1973, 12, $2321-2325$. [CrossRef]

138. Burgi, H.B.; Dunitz, J.D.; Shefter, E. Geometrical reaction coordinates. II. Nucleophilic addition to a carbonyl group. J. Am. Chem. Soc. 1973, 95, 5065-5067. [CrossRef]

139. Egli, M.; Gessner, R.V. Stereoelectronic effects of deoxyribose O4' on DNA conformation. Proc. Natl. Acad. Sci. USA 1995, 92, 180-184. [CrossRef] [PubMed]

140. Zahn, S.; Frank, R.; Hey-Hawkins, E.; Kirchner, B. Pnicogen bonds: A new molecular linker? Chem. Eur. J. 2011, 17, 6034-6038. [CrossRef] [PubMed]

141. Scheiner, S. A new noncovalent force: Comparison of $\mathrm{P} \cdots \mathrm{N}$ interaction with hydrogen and halogen bonds. J. Chem. Phys. 2011, 134, 094315. [CrossRef] [PubMed]

142. Del Bene, J.E.; Alkorta, I.; Sánchez-Sanz, G.; Elguero, J. ${ }^{31} \mathrm{P}-{ }^{31} \mathrm{P}$ spin-spin coupling constants for pnicogen homodimers. Chem. Phys. Lett. 2011, 512, 184-187. [CrossRef]

143. Del Bene, J.E.; Alkorta, I.; Elguero, J. The Pnicogen Bond in Review: Structures, Binding Energies, Bonding Properties, and Spin-Spin Coupling Constants of Complexes Stabilized by Pnicogen Bonds. Chall. Adv. Comput. Chem. Phys. 2015, 19, 191-264.

144. Scheiner, S. The pnicogen bond: Its relation to hydrogen, halogen, and other noncovalent bonds. Acc. Chem. Res. 2013, 46, 280-288. [CrossRef]

145. Li, W.; Spada, L.; Tasinato, N.; Rampino, S.; Evangelisti, L.; Gualandi, A.; Cozzi, P.G.; Melandri, S.; Barone, V.; Puzzarini, C. Theory meets experiment for noncovalent complexes: The puzzling case of pnicogen interactions. Angew. Chem. Int. Ed. 2018, 57, 13853-13857. [CrossRef]

146. Del Bene, J.E.; Alkorta, I.; Sánchez-Sanz, G.; Elguero, J. Structures, energies, bonding, and NMR properties of pnicogen complexes $\mathrm{H}_{2} \mathrm{XP}: \mathrm{NXH}_{2}\left(\mathrm{X}=\mathrm{H}, \mathrm{CH}_{3}, \mathrm{NH}_{2}, \mathrm{OH}, \mathrm{F}, \mathrm{Cl}\right)$. J. Phys. Chem. A 2011, 115, 13724-13731. [CrossRef]

147. Alkorta, I.; Sánchez-Sanz, G.; Elguero, J.; Del Bene, J.E. Influence of hydrogen bonds on the P...P pnicogen bond. J. Chem. Theor. Comput. 2012, 8, 2320-2327. [CrossRef]

148. Alkorta, I.; Elguero, J.; Del Bene, J.E. Pnicogen-bonded cyclic trimers $\left(\mathrm{PH}_{2} \mathrm{X}\right)_{3}$ with $\mathrm{X}=\mathrm{F}, \mathrm{Cl}, \mathrm{OH}, \mathrm{CN}, \mathrm{NC}$, $\mathrm{CH}_{3}, \mathrm{H}$, and $\mathrm{BH}_{2}$. J. Phys. Chem. A 2013, 117, 4981-4987. [CrossRef] [PubMed] 
149. Del Bene, J.E.; Alkorta, I.; Elguero, J. Influence of substituent effects on the formation of $\mathrm{P} \cdots \mathrm{Cl}$ pnicogen bonds or halogen bonds. J. Phys. Chem. A 2014, 118, 2360-2366. [CrossRef] [PubMed]

150. Del Bene, J.E.; Alkorta, I.; Elguero, J. Pnicogen-bonded complexes $\mathrm{H}_{n} \mathrm{~F}_{5-n} \mathrm{P}: \mathrm{N}-b a s e$, for $n=0-5$. J. Phys. Chem. A 2014, 118, 10144-10154. [CrossRef] [PubMed]

151. Alkorta, I.; Azofra, L.M.; Elguero, J. Ab initio study in the hydration process of metaphosphoric acid: The importance of the pnictogen interactions. Theor. Chem. Acta 2015, 134, 30. [CrossRef]

152. Alkorta, I.; Legon, A.C. Nucleophilicities of Lewis bases B and electrophilicities of Lewis acids A determined from the dissociation energies of complexes B ... A involving hydrogen bonds, tetrel bonds, pnictogen bonds, chalcogen bonds and halogen bonds. Molecules 2017, 22, 1786. [CrossRef] [PubMed]

153. Del Bene, J.E.; Alkorta, I.; Elguero, J. What types of noncovalent bonds stabilize dimers $(\mathrm{XCP})_{2}$, for $\mathrm{X}=\mathrm{CN}$, Cl, F, and H? J. Phys. Chem. A 2019, 123, 10086-10094. [CrossRef]

154. Guan, L.; Mo, Y. Electron transfer in pnicogen bonds. J. Phys. Chem. A 2014, 118, 8911-8921. [CrossRef]

155. Esrafili, M.D.; Mohammadian-Sabet, F. Pnicogen- pnicogen interactions in $\mathrm{O}_{2} \mathrm{XP}: \mathrm{PH}_{2} \mathrm{Y}$ complexes $(X=H, F$, $\mathrm{CN} ; \mathrm{Y}=\mathrm{H}, \mathrm{OH}, \mathrm{OCH}_{3}, \mathrm{CH}_{3}, \mathrm{NH}_{2}$ ). Chem. Phys. Lett. 2015, 638, 122-127. [CrossRef]

156. Zhuo, H.; Li, Q.; Li, W.; Cheng, J. The dual role of pnicogen as Lewis acid and base and the unexpected interplay between the pnicogen bond and coordination interaction in $\mathrm{H}_{3} \mathrm{~N} \cdots \mathrm{MCN}(\mathrm{X}=\mathrm{P}$ and $\mathrm{As} ; \mathrm{M}=\mathrm{Cu}$, $\mathrm{Ag}$, and Au). New J. Chem. 2015, 39, 2067-2074. [CrossRef]

157. Pecina, A.; Lepsík, M.; Hnyk, D.; Hobza, P.; Fanfrlík, J. Chalcogen and pnicogen bonds in complexes of neutral icosahedral and bicapped square-antiprismatic heteroboranes. J. Phys. Chem. A 2015, 119, 1388-1395. [CrossRef]

158. Wei, Y.; Li, Q.; Li, W.; Cheng, J.; McDowell, S.A.C. Influence of the protonation of pyridine nitrogen on pnicogen bonding: Competition and cooperativity. Phys. Chem. Chem. Phys. 2016, 18, 11348-11356. [CrossRef] [PubMed]

159. Ramanathan, N.; Sankaran, K.; Sundararajan, $\mathrm{K} . \mathrm{PCl}_{3}-\mathrm{C}_{6} \mathrm{H}_{6}$ heterodimers: Evidence for P $\cdots \pi$ phosphorus bonding at low temperatures. Phys. Chem. Chem. Phys. 2016, 18, 19350-19358. [CrossRef] [PubMed]

160. Wang, Y.; Zeng, Y.; Li, Z.; Meng, L.; Zhang, X. The mutual influence between $\pi$-hole pnicogen bonds and $\sigma$-hole halogen bonds in complexes of $\mathrm{PO}_{2} \mathrm{Cl}$ and $\mathrm{XCN} / \mathrm{C}_{6} \mathrm{H}_{6}(\mathrm{X}=\mathrm{F}, \mathrm{Cl}, \mathrm{Br})$. Struct. Chem. 2016, 27, 1427-1437. [CrossRef]

161. Schmauck, J.; Breugst, M. The potential of pnicogen bonding for catalysis-A computational study. Org. Biomol. Chem. 2017, 15, 8037-8045. [CrossRef]

162. Moaven, S.; Andrews, M.C.; Polaske, T.J.; Karl, B.M.; Unruh, D.K.; Bosch, E.; Bowling, N.P.; Cozzolino, A.F. Triple-pnictogen bonding as a tool for supramolecular assembly. Inorg. Chem. 2019, 58, 16227-16235. [CrossRef]

163. Scilabra, P.; Terraneo, G.; Daolio, A.; Baggioli, A.; Famulari, A.; Leroy, C.; Bryce, D.L.; Resnatti, G. 4,4'-Dipyridyl dioxide $\cdot \mathrm{SbF}_{3}$ co-crystal: Pnictogen bond prevails over halogen and hydrogen bonds in driving self-assembly. Cryst. Growth Des. 2020, 20, 916-922. [CrossRef]

164. Paulini, R.; Müller, K.; Diederich, F. Orthogonal multipolar interactions in structural chemistry and biology. Angew. Chem. Int. Ed. 2005, 44, 1788-1805. [CrossRef]

165. Fischer, F.R.; Schweizer, W.B.; Diederich, F. Molecular torsion balances: Evidence for favorable orthogonal dipolar interactions between organic fluorine and amide groups. Angew. Chem. Int. Ed. 2007, 46, 8270-8273. [CrossRef]

166. Fischer, F.R.; Wood, P.A.; Allen, F.H.; Diederich, F. Orthogonal dipolar interactions between amide carbonyl groups. Proc. Natl. Acad. Sci. USA 2008, 105, 17290-17294. [CrossRef]

167. Yap, G.P.A.; Jové, F.A.; Claramunt, R.M.; Sanz, D.; Alkorta, I.; Elguero, J. The X-ray molecular structure of 1-(2',4'-dinitrophenyl)-1,2,3-triazole and the problem of the orthogonal interaction between a 'pyridine-like' nitrogen and a nitro group. Aust. J. Chem. 2005, 58, 817-822. [CrossRef]

168. Pinilla, E.; Torres, M.R.; Claramunt, R.M.; Sanz, D.; Prakask, R.; Singh, S.P.; Alkorta, I.; Elguero, J. The structure of 2,3-dihydro-3-(2,4-dioxo-6-methylpyran-3-ylidene)-2-(2-nitrobenzyl)-1,4-benzo-thiazine and the problem of orthogonal interactions. Arkivoc 2006, 136-142. [CrossRef]

169. García, M.A.; Claramunt, R.M.; Elguero, J. ${ }^{13} \mathrm{C}$ and ${ }^{15} \mathrm{~N}$ NMR chemical shifts of 1-(2,4-dinitro-phenyl) and 1-(2,4,6-trinitrophenyl) pyrazoles in the solid state and in solution. Magn. Reson. Chem. 2008, 46, 697-700. [CrossRef] 
170. Alkorta, I.; Elguero, J.; Roussel, C.; Vanthuyne, N.; Piras, P. Atropisomerism and axial chirality in heteroaromatic compounds. Adv. Heterocycl. Chem. 2012, 105, 1-188.

171. Triballeau, N.; Van Name, E.; Laslier, G.; Cai, D.; Paillard, G.; Sorensen, P.W.; Hoffmann, R.; Bertrand, H.O.; Ngai, J.; Acher, F.C. High-potency olfactory receptor agonists discovered by virtual high-throughput screening: Molecular probes for receptor structure and olfactory function. Neuron 2008, 60, 767-774. [CrossRef]

172. Mahmudov, K.T.; Kopylovich, M.N.; Guedes da Silva, M.F.C.; Pombeiro, A.J.L. Chalcogen bonding in synthesis, catalysis and design of materials. Dalton Trans. 2016, 46, 10121-10138. [CrossRef]

173. Gleiter, R.; Haberhauer, G.; Werz, D.B.; Rominger, F.; Bleiholder, C. From noncovalent chalcogen-chalcogen interactions to supramolecular aggregates: Experiments and calculations. Chem. Rev. 2018, 118, 2010-2041. [CrossRef]

174. Vogel, L.; Wonner, P.; Huber, S.M. Chalcogen bonding: An overview. Angew. Chem. Int. Ed. 2019, 58, 1880-1891. [CrossRef] [PubMed]

175. Scilabra, P.; Terraneo, G.; Resnati, G. The chalcogen bond in crystalline solids: A world parallel to halogen bond. Acc. Chem. Res. 2019, 52, 1313-1324. [CrossRef] [PubMed]

176. Wang, W.; Ji, B.; Zhang, Y. Chalcogen bond: A sister noncovalent bond to halogen bond. J. Phys. Chem. A 2009, 113, 8132-8135. [CrossRef] [PubMed]

177. Minkin, V.I.; Sadekov, I.D.; Maksimenko, A.A.; Kompan, O.E. Molecular and crystal structure of ortho-tellurated azomethines with intramolecular $\mathrm{N} \rightarrow$ Te coordination. J. Organomet. Chem. 1991, 402, 331-348. [CrossRef]

178. Minyaev, R.M.; Minkin, V.I. Theoretical study of $\mathrm{O} \rightarrow \mathrm{X}(\mathrm{S}, \mathrm{Se}, \mathrm{Te})$ coordination in organic compounds. Can. J. Chem. 1998, 76, 776-788. [CrossRef]

179. Minkin, V.I.; Minyaev, R.M. Cyclic aromatic systems with hypervalent centers. Chem. Rev. 2001, 101, 1247-1265. [CrossRef] [PubMed]

180. Sanz, P.; Yáñez, M.; Mó, O. Competition between $X \cdots H \cdots Y$ intramolecular hydrogen bonds and $X \cdots Y(X=$ $\mathrm{O}, \mathrm{S}$, and $\mathrm{Y}=\mathrm{Se}, \mathrm{Te}$ ) chalcogen-chalcogen interactions. J. Phys. Chem. A 2002, 106, 4661-4668. [CrossRef]

181. Bleiholder, C.; Werz, D.B.; Köppel, H.; Gleiter, R. Theoretical investigations on chalcogen-chalcogen interactions: What makes these nonbonded interactions bonding? J. Am. Chem. Soc. 2006, 128, 2666-2674. [CrossRef]

182. Owczarzak, A.; Dutkiewicz, Z.; Kurczab, R.; Pietrús, W.; Kubicki, M.; Grzéskiewicz, A.M. Role of staple molecules in the formation of S...S contact in thioamides: Experimental charge density and theoretical studies. Cryst. Growth Des. 2019, 19, 7324-7335. [CrossRef]

183. Li, Q.Z.; Li, R.; Guo, P.; Li, H.; Li, W.Z.; Cheng, J.B. Competition of chalcogen bond, halogen bond, and hydrogen bond in SCS-HOX and SeCSe-HOX $(X=\mathrm{Cl}$ and $\mathrm{Br})$ complexes. Comput. Theor. Chem. 2012, 980, 56-61. [CrossRef]

184. Trujillo, C.; Sánchez-Sanz, G.; Alkorta, I.; Elguero, J. Halogen, chalcogen and pnictogen interaction in $\left(\mathrm{XNO}_{2}\right)_{2}$ homodimers (X = F, Cl, Br, I). New J. Chem. 2015, 39, 6791-6802. [CrossRef]

185. Esrafili, M.D.; Asadollahi, S.; Shaamat, Y.D. Competition between chalcogen bond and halogen bond interactions in $\mathrm{YOX}_{4}: \mathrm{NH}_{3}(\mathrm{Y}=\mathrm{S}, \mathrm{Se} ; \mathrm{X}=\mathrm{F}, \mathrm{Cl}, \mathrm{Br})$ complexes: An ab initio investigation. Struct. Chem. 2016, 27, 1439-1447. [CrossRef]

186. Alkorta, I.; Elguero, J.; Del Bene, J.E. Complexes of $\mathrm{O}=\mathrm{C}=\mathrm{S}$ with nitrogen bases: Chalcogen bonds, tetrel bonds, and other secondary interactions. ChemPhysChem 2018, 19, 1886-1894. [CrossRef]

187. Teng, Q.; Ng, P.S.; Leung, J.N.; Huynh, H.V. Donor strengths determination of pnictogen and chalcogen ligands by the Huynh electronic parameter and its correlation to sigma Hammett constants. Chem. Eur. J. 2019, 25, 13956-13963. [CrossRef]

188. Del Bene, J.E.; Alkorta, I.; Elguero, J. Exploring N ‥ C tetrel and O $\cdots$ S chalcogen bonds in HN (CH)SX:OCS systems, for $\mathrm{X}=\mathrm{F}, \mathrm{NC}, \mathrm{Cl}, \mathrm{CN}, \mathrm{CCH}$, and H. Chem. Phys. Lett. 2019, 730, 466-471. [CrossRef]

189. Del Bene, J.E.; Alkorta, I.; Elguero, J. Potential energy surfaces of $\mathrm{HN}(\mathrm{CH}) \mathrm{SX}: \mathrm{CO}_{2}$ systems, for $\mathrm{X}=\mathrm{F}, \mathrm{Cl}, \mathrm{NC}$, $\mathrm{CN}, \mathrm{CCH}$, and $\mathrm{H}: \mathrm{N} \cdots \mathrm{C}$ tetrel bonds and $\mathrm{O} \cdots \mathrm{S}$ chalcogen bonds. J. Phys. Chem. A 2019, 123, 7270-7277. [CrossRef] [PubMed]

190. Lu, J.; Scheiner, S. Effects of halogen, chalcogen, pnicogen, and tetrel bonds on IR and NMR spectra. Molecules 2019, 24, 2822. [CrossRef] [PubMed]

191. Esrafili, M.D.; Saeidi, N.; Solimannejad, M. Tuning of chalcogen bonds by cation- $\pi$ interactions: Cooperative and diminutive effects. J. Mol. Model. 2015, 21, 300. [CrossRef] [PubMed] 
192. Mó, O.; Montero-Campillo, M.M.; Alkorta, I.; Elguero, J.; Yáñez, M. Ternary complexes stabilized by chalcogen and alkaline-earth bonds: Crucial role of cooperativity and secondary noncovalent interactions. Chem. Eur. J. 2019, 25, 11688-11795. [CrossRef]

193. Sánchez-Sanz, G.; Trujillo, C.; Alkorta, I.; Elguero, J. Enhancing intramolecular chalcogen interactions in 1-hydroxy-YH-naphthalene derivatives. J. Phys. Chem. A 2017, 121, 8995-9003. [CrossRef]

194. Sánchez-Sanz, G.; Alkorta, I.; Elguero, J. Theoretical study of intramolecular interactions in peri-substituted naphthalenes: Chalcogen and hydrogen bonds. Molecules 2017, 22, 227. [CrossRef]

195. Sánchez-Sanz, G.; Trujillo, C.; Alkorta, I.; Elguero, J. Intermolecular weak interactions in HTeXH Dimers (X = $\mathrm{O}, \mathrm{S}, \mathrm{Se}, \mathrm{Te})$ : Hydrogen bonds, chalcogen-chalcogen contacts and chiral discrimination. ChemPhysChem 2012, 13, 496-503. [CrossRef]

196. Strakova, K.; Assies, L.; Goujon, A.; Piazzolla, F.; Humeniuk, H.V.; Matile, S. Dithienothiophenes at work: Access to mechanosensitive fluorescent probes, chalcogen-bonding catalysis, and beyond. Chem. Rev. 2019, 119, 10977-11005. [CrossRef]

197. Riwar, L.J.; Trapp, N.; Root, K.; Zenobi, R.; Diederich, F. Supramolecular capsules: Strong versus weak chalcogen bonding. Angew. Chem. Int. Ed. 2018, 57, 17259-17264. [CrossRef]

198. Ams, M.R.; Trapp, N.; Schwab, A.; Milic, J.V.; Diederich, F. Chalcogen bonding “2S-2N squares" versus competing interactions: Exploring the recognition properties of sulfur. Chem. Eur. J. 2019, 25, 323-333. [CrossRef] [PubMed]

199. Guo, N.; Maurice, R.; Teze, D.; Graton, J.; Champion, J.; Montavon, G.; Galland, N. Experimental and computational evidence of halogen bonds involving astatine. Nat. Chem. 2018, 10, 428-434. [CrossRef] [PubMed]

200. Metrangolo, P.; Neukirch, H.; Pilati, T.; Resnati, G. Halogen bonding based recognition processes: A world parallel to hydrogen bonding. Acc. Chem. Res. 2005, 38, 386-395. [CrossRef] [PubMed]

201. Gilday, L.C.; Robinson, S.W.; Barendt, T.A.; Langton, M.J.; Mullaney, B.R.; Beer, P.D. Halogen bonding in supramolecular chemistrt. Chem. Rev. 2015, 115, 7118-7195. [CrossRef] [PubMed]

202. Cavallo, G.; Metrangolo, P.; Milani, R.; Pilati, T.; Priimagi, A.; Resnati, G.; Terraneo, G. The halogen bond. Chem. Rev. 2016, 116, 2478-2601. [CrossRef]

203. Molina, P.; Zapata, F.; Caballero, A. Anion recognition strategies based on combined noncovalent interactions. Chem. Rev. 2017, 117, 9907-9972. [CrossRef]

204. Scheiner, S. Comparison of halide receptors based on $\mathrm{H}$, halogen, chalcogen, pnicogen, and tetrel bonds. Faraday Discuss. 2017, 203, 213-226. [CrossRef]

205. Huber, S.M.; Scanlon, J.D.; Jiménez-Izal, E.; Ugalde, J.M.; Infante, I. On the directionality of halogen bonding. Phys. Chem. Chem. Phys. 2013, 15, 10350-10357. [CrossRef]

206. Riley, K.E.; Murray, J.S.; Fanfrlík, J.; Řezáč, J.; Solá, R.J.; Concha, M.C.; Ramos, F.M.; Politzer, P. Halogen bond tunability I: The effects of aromatic fluorine substitution on the strengths of halogen-bonding interactions involving chlorine, bromine, and iodine. J. Mol. Model. 2011, 17, 3309-3318. [CrossRef]

207. Riley, K.E.; Murray, J.S.; Fanfrlík, J.; Řezáč, J.; Solá, R.J.; Concha, M.C.; Ramos, F.M.; Politzer, P. Halogen bond tunability II: The varying roles of electrostatic and dispersion contributions to attraction in halogen bonds. J. Mol. Model. 2013, 19, 4651-4659. [CrossRef]

208. Chan, Y.C.; Yeung, Y.Y. Halogen Bond Catalyzed Bromocarbocyclization. Angew. Chem. Int. Ed. 2018, 57, 3483-3487. [CrossRef] [PubMed]

209. Carreras, L.; Serrano-Torné, M.; van Leeuwen, P.W.N.M.; Vidal-Ferran, A. XBphos-Rh: A halogen-bond assembled supramolecular catalyst. Chem. Sci. 2018, 9, 3644-3648. [CrossRef] [PubMed]

210. Lieffrig, J.; Jeannin, O.; Fourmigué, M. Expanded halogen-bonded anion organic networks with star-shaped iodoethynyl-substituted molecules: From corrugated $2 \mathrm{~d}$ hexagonal lattices to pyrite-type 2-fold interpenetrated cubic lattices. J. Am. Chem. Soc. 2013, 135, 6200-6210. [CrossRef] [PubMed]

211. Kumar, V.; Pilati, T.; Terraneo, G.; Meyer, F.; Metrangolo, P.; Resnati, G. Halogen bonded Borromean networks by design: Topology invariance and metric tuning in a library of multi-component systems. Chem. Sci. 2017, 8, 1801-1810. [CrossRef] [PubMed]

212. Edwards, A.J.; Mackenzie, C.F.; Spackman, P.R.; Jayatilaka, D.; Spackman, M.A. Intermolecular interactions in molecular crystals: what's in a name? Faraday Discuss. 2017, 203, 93-112. [CrossRef] [PubMed]

213. Politzer, P.; Murray, J.S. $\sigma$-Hole interactions: Perspectives and misconceptions. Crystals 2017, 7, 212. [CrossRef] 
214. Clark, T.; Hennemann, M.; Murray, J.S.; Politzer, P. Halogen bonding: The $\sigma$-hole. J. Mol. Model. 2007, 13, 291-296. [CrossRef]

215. Desiraju, G.R.; Ho, P.S.; Kloo, L.; Legon, A.C.; Marquardt, R.; Metrangolo, P.; Politzer, P.; Resnati, G.; Rissanen, K. Definition of the halogen bond (IUPAC recommendations 2013). Pure Appl. Chem. 2013, 85, 1711-1713. [CrossRef]

216. Catalano, L.; Pérez-Estrada, S.; Terraneo, G.; Pilati, T.; Resnati, G.; Metrangolo, P.; García-Garibay, M.A. Dynamic characterization of crystalline supramolecular rotors assembled through halogen bonding. J. Am. Chem. Soc. 2015, 137, 15386-15389. [CrossRef]

217. Catalano, L.; Pérez-Estrada, S.; Wang, H.H.; Ayitou, A.J.L.; Khan, S.I.; Terraneo, G.; Metrangolo, P.; Brown, S.; García-Garibay, M.A. Rotational dynamics of diazabicyclo[2.2.2]octane in isomorphous halogen-bonded co-crystals: Entropic and enthalpic effects. J. Am. Chem. Soc. 2017, 139, 843-848. [CrossRef]

218. Lemouchi, C.; Vogelsberg, C.S.; Zorina, L.; Simonov, S.; Batail, P.; Brown, S.; García-Garibay, M.A. Ultra-fast rotors for molecular machines and functional materials via halogen bonding: Crystals of 1,4-bis(iodoethynyl)bicyclo[2.2.2] octane with distinct gigahertz rotation at two sites. J. Am. Chem. Soc. 2011, 133, 6371-6379. [CrossRef] [PubMed]

219. Ivanov, D.M.; Novikov, A.S.; Ananyev, I.V.; Kirina, Y.V.; Kukushkin, V.Y. Halogen bonding between metal centers and halocarbons. Chem. Commun. 2016, 55, 5565-5568. [CrossRef] [PubMed]

220. Baykov, S.V.; Dabranskaya, U.; Ivanov, D.M.; Novikov, A.S.; Boyarskiy, V.P. Pt/Pd and I/Br isostructural exchange provides formation of $\mathrm{C}-\mathrm{I} \cdots \mathrm{Pd}, \mathrm{C}-\mathrm{Br} \cdots \mathrm{Pt}$, and $\mathrm{C}-\mathrm{Br} \cdots \mathrm{Pd}$ metal-involving halogen bonding. Cryst. Growth Des. 2018, 18, 5973-5980. [CrossRef]

221. Rozhkov, A.V.; Krykova, M.A.; Ivanov, D.M.; Novikov, A.S.; Sinelshchikova, A.A.; Volostnykh, M.V.; Konovalov, M.A.; Grigoriev, M.S.; Gorbunova, Y.G.; Kukushkin, V.Y. Reverse arene sandwich structures based upon $\pi$-hole $\cdots\left[\mathrm{M}^{\mathrm{II}}\right]\left(\mathrm{d}^{8} \mathrm{M}=\mathrm{Pt}\right.$, Pd) interactions, where positively charged metal centers play the role of a nucleophile. Angew. Chem. Int. Ed. 2019, 58, 4164-4168. [CrossRef]

222. El Kerdawy, A.; Murray, J.S.; Politzer, P.; Bleiziffer, P.; Hesselmann, A.; Görling, A.; Clark, T. Advanced corrections of hydrogen bonding and dispersion for semiempirical quantum mechanical methods. J. Chem. Theory Comput. 2013, 9, 2264-2275. [CrossRef]

223. Clark, T. Halogen bonds and $\sigma$-holes. Faraday Discuss. 2017, 203, 9-27. [CrossRef]

224. Sedlak, R.; Kolár, M.H.; Hobza, P. Polar flattening and the strength of halogen bonding. J. Chem. Theory Comput. 2015, 11, 4727-4732. [CrossRef]

225. Kolár, M.H.; Hobza, P. Computer modelling of halogen bonds and other $\sigma$-hole interactions. Chem. Rev. 2016, 116, 5155-5187. [CrossRef]

226. Costa, P.J. The halogen bond: Nature and applications. Phys. Sci. Rev. 2017, 20170136. [CrossRef]

227. Metrangolo, P.; Resnati, G. (Eds.) Halogen Bonding I. Impact on Materials Chemistry and Life Sciences. In Topics in Current Chemistry; Springer: Cham, Switzerland, 2015; Volume 358.

228. Metrangolo, P.; Meyer, F.; Pilati, T.; Resnati, G.; Terraneo, G. Halogen bonding in supramolecular chemistry. Angew. Chem. Int. Ed. 2008, 47, 6114-6127. [CrossRef]

229. Reddy, C.M.; Kirchner, M.T.; Gundakaram, R.C.; Padmanabhan, K.A.; Desiraju, G.R. Isostructurality, polymorphism and mechanical properties of some hexahalogenated benzenes: The nature of halogen $\cdots$ halogen interactions. Chem. Eur. J. 2006, 12, 2222-2234. [CrossRef] [PubMed]

230. Politzer, P.; Riley, K.E.; Bulat, F.A.; Murray, J.S. Perspectives on halogen bonding and other $\sigma$-hole interactions: Lex parsimoniae (Occam's razor). Comput. Theor. Chem. 2012, 998, 2-8. [CrossRef]

231. Zou, J.W.; Jiang, Y.J.; Guo, M.; Hu, G.X.; Zhang, B.; Liu, H.C.; Yu, Q.S. Ab initio study of the complexes of halogen-containing molecules $\mathrm{RX}(\mathrm{X}=\mathrm{Cl}, \mathrm{Br}$, and $\mathrm{I})$ and $\mathrm{NH}_{3}$ : Towards understanding the nature of halogen bonding and the electron-accepting propensities of covalently bonded halogen atoms. Chem. Eur. J. 2005, 11, 740-751. [CrossRef] [PubMed]

232. Lu, Y.X.; Zou, J.W.; Wang, Y.H.; Jiang, Y.J.; Yu, Q.S. Ab initio investigation of the complexes between bromobenzene and several electron donors: Some insights into the magnitude and nature of halogen bonding interactions. J. Phys. Chem. A 2007, 111, 10781-10788. [CrossRef] [PubMed]

233. An, X.; Jing, B.; Li, Q. Novel halogen-bonded complexes $\mathrm{H}_{3} \mathrm{NBH}_{3} \cdots \mathrm{XY}(\mathrm{XY}=\mathrm{ClF}, \mathrm{ClCl}, \mathrm{BrF}, \mathrm{BrCl}$, and $\mathrm{BrBr})$ : Partially covalent character. J. Phys. Chem. A 2010, 114, 6438-6443. [CrossRef] 
234. Esrafili, M.D.; Vakili, M.; Solimannejad, M. Characterization of halogen $\cdots$ halogen interactions in crystalline dihalomethane compounds $\left(\mathrm{CH}_{2} \mathrm{Cl}_{2}, \mathrm{CH}_{2} \mathrm{Br}_{2}\right.$ and $\left.\mathrm{CH}_{2} \mathrm{I}_{2}\right)$ : A theoretical study. J. Mol. Model. 2014, 20, 2102. [CrossRef]

235. Kozuch, S.; Martin, J.M.L. Halogen bonds: Benchmarks and theoretical analysis. J. Chem. Theor. Comput. 2013, 9, 1918-1931. [CrossRef]

236. Bauzá, A.; Frontera, A. Aerogen bonding interactions: A new supramolecular force? Angew. Chem. Int. Ed. 2015, 54, 7340-7343. [CrossRef]

237. Bauzá, A.; Frontera, A. $\sigma / \pi$-Hole noble gas bonding interactions: Insights from theory and experiment. Coord. Chem. Rev. 2020, 404, 213112. [CrossRef]

238. Goettel, J.T.; Haensch, V.G.; Schrobilgen, G.J. Stable chloro- and bromoxenate cage anions; $\left[\mathrm{X}_{3}\left(\mathrm{XeO}_{3}\right)_{3}\right]^{3-}$ and $\left[\mathrm{X}_{4}\left(\mathrm{XeO}_{3}\right)_{4}\right]^{4-}(\mathrm{X}=\mathrm{Cl}$ or Br$)$. J. Am. Chem. Soc. 2017, 139, 8725-8733. [CrossRef]

239. Goettel, J.T.; Matsumoto, K.; Mercier, H.P.A.; Schrobilgen, G.J. Syntheses and structures of xenon trioxide alkylnitrile adducts. Angew. Chem. Int. Ed. 2016, 55, 13780-13783. [CrossRef] [PubMed]

240. Britvin, S.N.; Kashtanov, S.A.; Krivovichev, S.V.; Chukanov, N.V. Xenon in rigid oxide frameworks: Structure, bonding and explsive properties of layered perovskite $\mathrm{K}_{4} \mathrm{Xe}_{3} \mathrm{O}_{12}$. J. Am. Chem. Soc. 2016, 138, 13838-13841. [CrossRef] [PubMed]

241. Britvin, S.N.; Kashtanov, S.A.; Krzhizhanovskaya, M.G.; Gurinov, A.A.; Glumov, O.V.; Strekopytov, S.; Kretser, Y.L.; Zaitsev, A.N.; Chukanov, N.V.; Krivovichev, S.V. Perovskites with the framework-forming xenon. Angew. Chem. Int. Ed. 2015, 54, 14340-14344. [CrossRef] [PubMed]

242. Makarewicz, E.; Lundell, J.; Gordon, A.J.; Berski, S. On the nature of interactions in the $\mathrm{F}_{2} \mathrm{OXe}^{\cdots \mathrm{NCCH}_{3}}$ complex: Is there the Xe (IV)-N bond? J. Comput. Chem. 2016, 37, 1876-1886. [CrossRef] [PubMed]

243. Miao, J.; Xiong, Z.; Gao, Y. The effects of aerogen-bonding on the geometries and spectral properties of several small molecular clusters containing $\mathrm{XeO}_{3}$. J. Phys. Condens. Matter. 2018, 30, 44. [CrossRef] [PubMed]

244. Borocci, S.; Grandinetti, F.; Sanna, N.; Antoniotti, P.; Nunzi, F. Noncovalent complexes of the noble-gas atoms: Analyzing the transition from physical to chemical interactions. J. Comput. Chem. 2019, 40, 2318-2328. [CrossRef] [PubMed]

245. Weinhold, F.; Landis, C.R. Valency and Bonding: A Natural Bond. Orbital Donor-Acceptor Perspective; Cambridge University Press: Cambridge, UK, 2005.

246. Bauzá, A.; Frontera, A. Theoretical study on the dual behavior of $\mathrm{XeO}_{3}$ and $\mathrm{XeF}_{4}$ toward aromatic rings: Lone pair- $\pi$ versus aerogen $-\pi$ interactions. ChemPhysChem 2015, 16, 3625-3630. [CrossRef]

247. Gao, M.; Cheng, J.; Li, W.; Xiao, B.; Li, Q. The aerogen- $\pi$ bonds involving $\pi$ systems. Chem. Phys. Lett. 2016, 651, 50-55. [CrossRef]

248. Zierkiewicz, W.; Michalczyk, M.; Scheiner, S. Aerogen bonds formed between AeOF2 (Ae = Kr, Xe) and diazines: Comparisons between $\sigma$-hole and $\pi$-hole complexes. Phys. Chem. Chem. Phys. 2018, 20, 4676-4687. [CrossRef]

249. Esrafili, M.D.; Asadollahi, S.; Vakili, M. Investigation of substituent effects in aerogen-bonding interactions between $\mathrm{ZO}_{3}(\mathrm{Z}=\mathrm{Kr}, \mathrm{Xe})$ and nitrogen bases. Int. J. Quantum Chem. 2016, 116, 1254-1260. [CrossRef]

250. Esrafili, M.D.; Mohammadian-Sabet, F. Exploring “aerogen-hydride" interactions between $\mathrm{ZOF}_{2}(\mathrm{Z}=\mathrm{Ke}, \mathrm{Xe})$ and metal hydrides: An ab initio study. Chem. Phys. Lett. 2016, 654, 23-28. [CrossRef]

251. Esrafili, M.D.; Mohammadian-Sabet, F.; Solimannejad, M. Single-electron aerogen bonds: Do they exist? Chem. Phys. Lett. 2016, 659, 196-202. [CrossRef]

252. Esrafili, M.D.; Mohammadian-Sabet, F. An ab initio study on anionic aerogen bonds. Chem. Phys. Lett. 2017, 667, 337-344. [CrossRef]

253. Esrafili, M.D.; Sadr-Mousavi, A. A computational study on the strength and nature of bifurcated aerogen bonds. Chem. Phys. Lett. 2018, 698,1-6. [CrossRef]

254. Hou, C.; Wang, X.; Botanab, J.; Miao, M. Noble gas bond and the behaviour of $\mathrm{XeO}_{3}$ under pressure. Phys. Chem. Chem. Phys. 2017, 19, 27463-27467. [CrossRef]

255. Esrafili, M.D.; Vessally, E. A theoretical evidence for cooperative enhancement in aerogen-bonding interactions: Open-chain clusters of $\mathrm{KrOF}_{2}$ and $\mathrm{XeOF}_{2}$. Chem. Phys. Lett. 2016, 662, 80-85. [CrossRef]

256. Esrafili, M.D.; Vessally, E. The strengthening of a hydrogen or lithium bond on the $Z \cdots N$ aerogen bond ( $Z=$ $\mathrm{Ar}, \mathrm{Kr}$ and Xe): A comparative study. Mol. Phys. 2016, 114, 3265-3276. [CrossRef] 
257. Esrafili, M.D.; Kiani, H. Cooperativity between the hydrogen bonding and $\sigma$-hole interaction in linear $\mathrm{NCX} \cdots(\mathrm{NCH})_{n=2-5}$ and $\mathrm{O}_{3} \mathrm{Z} \cdots(\mathrm{NCH})_{n=2-5}$ complexes $(\mathrm{X}=\mathrm{Cl}, \mathrm{Br} ; \mathrm{Z}=\mathrm{Ar}, \mathrm{Kr})$ : A comparative study. Can. J. Chem. 2017, 95, 537-546. [CrossRef]

258. Esrafili, M.D.; Mousavian, P.; Mohammadian-Sabet, F. The influence of hydrogen- and lithium-bonding on the cooperativity of chalcogen bonds: A comparative ab initio study. Mol. Phys. 2019, 117, 58-66. [CrossRef]

259. Esrafili, M.D.; Qasemsolb, S. Tuning aerogen bonds via anion- $\pi$ or lone pair- $\pi$ interaction: A comparative ab initio study. Struct. Chem. 2017, 28, 1255-1264. [CrossRef]

260. Alkorta, I.; Rozas, I.; Elguero, J. An attractive interaction between the $\pi$-cloud of $\mathrm{C}_{6} \mathrm{~F}_{6}$ and electron-donor atoms. J. Org. Chem. 1997, 62, 4687-4691. [CrossRef]

261. Buglioni, L.; Mastandrea, M.M.; Frontera, A.; Pericás, M.A. Anion- $\pi$ interactions in light-induced reactions: Role in the amidation of (hetero)aromatic systems with activated $\mathrm{N}$-aryloxyamides. Chem. Eur. J. 2019, 25, 11785-11790. [CrossRef] [PubMed]

262. Leffler, J.E.; Grunwald, E. Rates and Equilibria of Organic Reactions: As Treated by Statistical, Thermodynamic and Extrathermodynamic Methods (Dover Books on Chemistry); Kindle Edition; Dover Publications: Mignola, NY, USA, 1989.

263. Matheron, G. Principles of geostatistics. Econ. Geol. 1963, 58, 1246-1266. [CrossRef]

264. Mayr, H.; Breugst, M.; Ofial, A.R. Farewell to the HSAB treatment of ambident reactivity. Angew. Chem. Int. Ed. 2011, 50, 6470-6505. [CrossRef] [PubMed]

265. Chandrakumar, K.R.S.; Pal, S. A systematic study on the reactivity of Lewis acid-base complexes through the local Hard-Soft Acid-Base principle. J. Phys. Chem. A 2002, 106, 11775-11781. [CrossRef]

266. Drago, R.S.; Vogel, G.C.; Needham, T.E. A four-parameter equation for predicting enthalpies of adduct formation. J. Am. Chem. Soc. 1971, 93, 6014-6026. [CrossRef]

267. Drago, R.S.; Dadmun, A.P.; Vogel, G.C. Addition of new donors to the $E$ and $C$ model. Inorg. Chem. 1993, 32, 2473-2479. [CrossRef]

268. Hancock, R.D.; Nakani, B.S.; Marsicano, F. Relationship between Lewis acid-base behavior in the gas phase and in aqueous solution. 1. Role of inductive, polarizability, and steric effects in amine ligands. Inorg. Chem. 1983, 22, 2531-2535. [CrossRef]

269. Hosmane, R.S.; Liebman, J.F. Paradoxes and paradigms: Why is quinoline less basic than pyridine or isoquinoline? A classical organic chemical perspective. Struct. Chem. 2009, 20, 693-697. [CrossRef]

270. Yamaguchi, I. Nuclear Magnetic Resonance study of the steric effect in dimethylphenols. Bull. Chem. Soc. Jpn. 1961, 34, 744-747. [CrossRef]

271. Chisholm, J.; Pidcock, E.; van de Streek, J.; Infantes, L.; Motherwell, S.; Allen, F.H. Knowledge-based approaches to crystal design. CrystEngComm 2006, 8, 11-28. [CrossRef]

272. Delori, A.; Galek, P.T.A.; Pidcock, E.; Jones, W. Quantifying homo- and heteromolecular hydrogen bonds as a guide for adduct formation. Chem. Eur. J. 2012, 18, 6835-6846. [CrossRef] [PubMed]

273. Romero-Fernández, M.P.; Avalos, M.; Babiano, R.; Cintas, P.; Jiménez, J.L.; Palacios, J.C. A further look at $\pi$-delocalization and hydrogen bonding in 2-arylmalondialdehydes. Tetrahedron 2016, 72, 95-104. [CrossRef]

274. Stephan, D.W. "Frustrated Lewis pairs": A concept for new reactivity and catalysis. Org. Biomol. Chem. 2008, 6, 1535-1539. [CrossRef]

275. Stephan, D.W.; Erker, G. Frustrated Lewis Pairs chemistry: Development and perspectives. Angew. Chem. Int. Ed. 2015, 54, 6400-6441. [CrossRef] [PubMed]

276. Pu, M.; Privalov, T. Chemistry of intermolecular frustrated Lewis pairs in motion: Emerging perspectives and prospects. Isr. J. Chem. 2015, 55, 179-195. [CrossRef]

277. Hill, M.S.; Liptrot, D.J.; Weetman, C. Alkaline earths as main group reagents in molecular catalysis. Chem. Soc. Rev. 2016, 45, 972-988. [CrossRef] [PubMed]

278. Rohman, S.S.; Kashyap, C.; Ullah, S.S.; Guha, A.K. Designing metal-free frustrated Lewis pairs for dihydrogen activation based on a carbene-borane system. Polyhedron 2019, 162, 1-7. [CrossRef]

279. Cahn, R.S.; Ingold, C.; Prelog, V. Specification of molecular chirality. Angew. Chem. Int. Ed. 1966, 5, 385-415. [CrossRef]

280. Prelog, V.; Helmchen, G. Basic principles of the CIP-system and proposals for a revision. Angew. Chem. Int. Ed. 1982, 21, 567-583. [CrossRef] 
281. Alkorta, I.; Elguero, J.; Cintas, P. Adding only one priority rule allows extending CIP rules to supramolecular systems. Chirality 2015, 27, 339-343. [CrossRef] [PubMed]

282. Elguero, J. Is it possible to extend the Cahn-Ingold-Prelog priority rules to supramolecular structures and coordination compounds using lone pairs? Chem. Int. 2016, 30-31. [CrossRef]

(C) 2020 by the authors. Licensee MDPI, Basel, Switzerland. This article is an open access article distributed under the terms and conditions of the Creative Commons Attribution (CC BY) license (http://creativecommons.org/licenses/by/4.0/). 